\title{
Preferred response of the East Asian summer monsoon to local and non-local anthropogenic sulphur dioxide emissions
}

\author{
Buwen Dong $^{1} \cdot$ Rowan T. Sutton $^{1} \cdot$ Eleanor J. Highwood $^{2} \cdot$ Laura J. Wilcox $^{1}$
}

Received: 29 October 2014 / Accepted: 18 May 2015 / Published online: 28 May 2015

(C) The Author(s) 2015. This article is published with open access at Springerlink.com

\begin{abstract}
In this study, the atmospheric component of a state-of-the-art climate model (HadGEM2-ES) that includes earth system components such as interactive chemistry and eight species of tropospheric aerosols considering aerosol direct, indirect, and semi-direct effects, has been used to investigate the impacts of local and non-local emissions of anthropogenic sulphur dioxide on the East Asian summer monsoon (EASM). The study focuses on the fast responses (including land surface feedbacks, but without sea surface temperature feedbacks) to sudden changes in emissions from Asia and Europe. The initial responses, over days 1-40, to Asian and European emissions show large differences. The response to Asian emissions involves a direct impact on the sulphate burden over Asia, with immediate consequences for the shortwave energy budget through aerosol-radiation and aerosol-cloud interactions. These changes lead to cooling of East Asia and a weakening of the EASM. In contrast, European emissions have no significant impact on the sulphate burden over Asia, but they induce mid-tropospheric cooling and drying over the European sector. Subsequently, however, this cold and dry anomaly is advected into Asia, where it induces atmospheric and surface feedbacks over Asia and the Western North Pacific (WNP), which also weaken the EASM. In spite of very different perturbations to the local aerosol burden in response to Asian and European sulphur dioxide
\end{abstract}

Buwen Dong

b.dong@ reading.ac.uk

1 National Centre for Atmospheric Science,

Department of Meteorology, University of Reading, Reading RG6 6BB, UK

2 Department of Meteorology, University of Reading, Reading, UK emissions, the large scale pattern of changes in land-sea thermal contrast, atmospheric circulation and local precipitation over East Asia from days 40 onward exhibits similar structures, indicating a preferred response, and suggesting that emissions from both regions likely contributed to the observed weakening of the EASM. Cooling and drying of the troposphere over Asia, together with warming and moistening over the WNP, reduces the land-sea thermal contrast between the Asian continent and surrounding oceans. This leads to high sea level pressure (SLP) anomalies over Asia and low SLP anomalies over the WNP, associated with a weakened EASM. In response to emissions from both regions warming and moistening over the WNP plays an important role and determines the time scale of the response.

Keywords East Asian summer monsoon - Aerosolradiation and aerosol-cloud interactions $\cdot$ Land-sea thermal contrast $\cdot$ Fast responses

\section{Introduction}

The East Asian summer monsoon (EASM), driven by temperature differences between the Asian continent and the Indian and Pacific Oceans, influences the climate in most East Asian countries (Webster 1987; Tao and Chen 1987). Since the late 1970s, the EASM has exhibited a considerable weakening trend, and a southward shift of the main rain belt, known as the southern flooding and northern drought (SFND) pattern (Yu et al. 2004; Yang and Zhu 2008; Ding et al. 2008, 2009; Wang et al. 2013). This change of the EASM has been suggested to be caused by many factors (Zhou et al. 2009), including sea surface temperature (SST) variability (Yang and Zhu 2008; Li et al. 2010; Fu 
and Li 2013), decadal changes in sensible heat flux over the Tibetan Plateau (Ding et al. 2009; Duan et al. 2013), anthropogenic aerosol (Xu 2001; Menon et al. 2002; Huang et al. 2007; Liu et al. 2009, 2011; Chen et al. 2012; Zhang et al. 2012; Guo et al. 2013; Hwang et al. 2013; Jiang et al. 2013; Ye et al. 2013; Wang et al. 2013; Zhou et al. 2013; Polson et al. 2014; Song et al. 2014), and natural decadal variability (Lei et al. 2011).

East Asia, especially East China is one of the most polluted regions in the world because of its rapid economic development in recent decades. Total anthropogenic emissions of sulphur dioxide $\left(\mathrm{SO}_{2}\right)$, the source gas for sulphate aerosol, in China increased by more than a factor of 5 from the 1950s to the 2000s, with most of the increase taking place after the 1970s (State Environmental Protection Administration of China 2005). Anthropogenic aerosols can affect cloud and precipitation through their interactions with radiation and cloud (e.g. Hansen et al. 1997; Rosenfeld et al. 2008; Stevens and Feingold 2009; Tao et al. 2012). By scattering and absorbing solar radiation, aerosols can change surface and atmospheric temperature. Aerosol also interacts directly with cloud by serving as cloud condensation nuclei (CCN) or ice nuclei (IN), leading to changes in cloud droplet number concentration (CDNC), cloud droplet size, cloud radiative properties and precipitation efficiency (e.g. Twomey 1977; Rosenfeld et al. 2008). The radiative and cloud processes can interact with each other and produce complex aerosol effects on clouds and precipitation, both locally and remotely to emission (e.g. Chou et al. 2005; Tao et al. 2012; Wan et al. 2013; Wang 2013; Bollasina et al. 2014).

Therefore, anthropogenic aerosols have the potential to affect the EASM and precipitation. Gu et al. (2006) found that a SFND response pattern due to the scattering effect of sulphate, which cooled the mid-latitudes and led to a strengthening of the Hadley circulation. Allen and Sherwood (2010) showed a large-scale land-sea contrast, with general increases in ocean clouds, and decreases in land clouds due to global anthropogenic aerosol changes. Wang et al. (2013) used a coupled ocean-atmosphere general circulation model and multi-ensemble simulations to argue that the SFND pattern is mainly caused by the combined effect of increasing global greenhouse gases and regional aerosol emissions over China. Similar conclusions that anthropogenic aerosols suppress the precipitation in North China and enhance the precipitation in South China were reached by Jiang et al. (2013).

Cowan and Cai (2011) investigated the role of Asian versus non-Asian anthropogenic aerosols on the EASM and showed that Asian aerosols induce a weakening EASM. The addition of non-Asian aerosols generated an enhancement and broadening of cooler temperatures over Europe and Asia relative to the ambient oceans, supporting stronger northerly flows that further suppress Asian monsoon rainfall, highlighting the importance of the non-Asian aerosols in exacerbating the impact of Asian aerosols on monsoon rainfall across Asia. Liu et al. (2009) and Guo et al. (2013) investigated the role of both sulphur dioxide and black carbon (BC) emissions over Asia on the EASM and concluded that regional sulphate aerosols have a more important impact on the EASM than BC. Guo et al. (2013) further found that the impacts of aerosols are more significant during the withdrawal phase of the EASM (September) rather than active phase (June, July, August).

These previous studies have demonstrated that anthropogenic aerosols are an important driver of changes in the EASM, but many questions remain open. In particular, there are important questions about the exact mechanisms that govern the response of the EASM to emissions from different regions. In this study, we investigate the transient responses to an abrupt change in sulphur dioxide emissions from specific regions (Asia and Europe) in order to study physical processes of the EASM changes, using simulations with an atmospheric general circulation model. We chose to study the impacts of sulphur dioxide emissions since previous studies indicated that regional sulphate aerosols have a more important impact on the EASM than BC (e.g., Liu et al. 2009; Guo et al. 2013). A similar approach was used in Dong et al. (2009) to investigate the transient adjustment of the atmosphere and land surface in response to an instantaneous doubling of $\mathrm{CO}_{2}$, and in Dong et al. (2014) to investigate transient adjustment of the West African Monsoon to abrupt changes in regional sulphur dioxide emissions. By investigating the transient evolution with daily time resolution we are able to disentangle processes evolving on different timescales. In addition, we are able to investigate to what extent the processes that govern responses to emissions from different regions (Asia and Europe) are similar or different.

The structure of the paper is as follows. Section 2 describes the model used and experiments performed. Section 3 presents seasonal mean responses of the EASM to regional sulphur dioxide emissions. Section 4 discusses the time evolution of responses and elucidates the physical processes involved. Conclusions are in Sect. 5.

\section{Model and experiments}

\subsection{Model and experiments}

The model used is the atmospheric component of the UK Met Office Hadley Centre Earth system model HadGEM2ES (Collins et al. 2011; Jones et al. 2011; Bellouin et al. 2011). The atmospheric resolution is $\mathrm{N} 96\left(1.875^{\circ}\right.$ by $\left.1.25^{\circ}\right)$ with 38 vertical levels with the model top at $\sim 39 \mathrm{~km}$. 


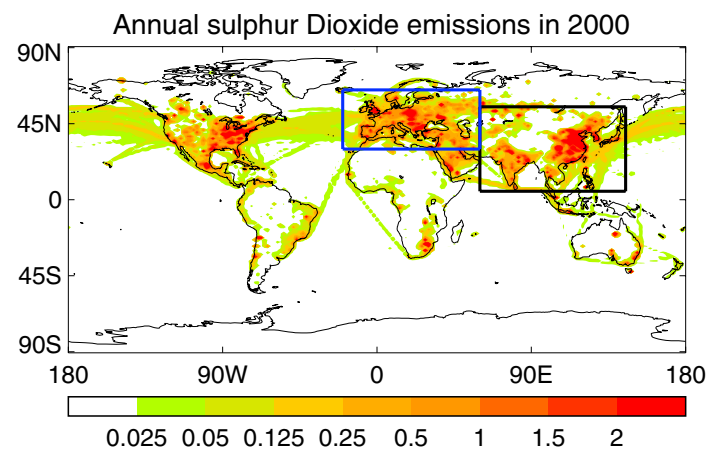

Fig. 1 Annual mean sulphur dioxide emissions $\left(\mathrm{g} \mathrm{m}^{-2}\right.$ year $\left.^{-1}\right)$ in year 2000 with the black and blue boxes highlighting Asia and Europe where emissions are set to zero in sensitivity experiments (Table 1)

HadGEM2-ES includes an interactive land and ocean carbon cycle as well as a dynamic vegetation model. The model includes earth system components such as an interactive tropospheric chemistry scheme and eight species of tropospheric aerosols, including ammonium sulphate, mineral dust, sea salt, fossil fuel black carbon, fossil fuel organic carbon, biomass burning aerosols, secondary organic and ammonium nitrate aerosols. The direct radiative effect due to scattering and absorption of radiation by all eight aerosol species represented in the model is included. The semidirect effect, whereby aerosol absorption tends to change cloud formation by warming the aerosol layer, is included implicitly. The parameterization of the indirect effects is described in detail by Jones et al. (2001). The CDNC is calculated from the number concentration of the accumulation and dissolved modes of hygroscopic aerosols. For the first indirect effect, the radiation scheme uses the CDNC to obtain the cloud droplet effective radius (CDER). For the second indirect effects, the large scale precipitation scheme uses the CDNC to compute the autoconversion rate of cloud water to rainwater. The detailed descriptions of the aerosol module are given in Bellouin et al. (2011). The historical emissions for tropospheric aerosols and aerosol precursors are described by Lamarque et al. (2010). Data sets required by HadGEM2-ES for tropospheric aerosol modelling are emissions of sulphur dioxide $\left(\mathrm{SO}_{2}\right)$, land-based dimethyl sulphide (DMS), ammonia $\left(\mathrm{NH}_{3}\right)$, and primary black and organic carbon aerosols from fossil fuel combustion and biomass burning. Emissions of sea-salt, mineral dust, and ocean-based DMS, are computed interactively. HadGEM2-ES participates in the CMIP5 simulations and the validation of model aerosols and their radiative forcing has been documented in Bellouin et al. (2011).

Figure 1 shows the annual mean emissions of $\mathrm{SO}_{2}$ in 2000 (Lamarque et al. 2010). South and East Asia, Western Europe, and the east coast of USA are the stronger emission regions. The same experiments as performed in Dong et al. (2014) are used in this study to investigate the responses of the EASM to sudden changes in Asian and European sulphur dioxide emissions, and they are summarized in Table 1. The CONTROL experiment is forced by monthly climatological SST and sea ice averaged over the period of 1986-2005 from HadISST (Rayner et al. 2003), with well mixed greenhouse gas concentrations and all species of aerosol and related emissions as in 2000. The sulphur dioxide emissions have seasonal cycles, but they are very weak (not shown). Two sensitivity experiments, NOASIA and NO-EUROPE, have been performed in which the sulphur dioxide emissions over Asia or Europe have been removed, respectively, everything else remaining as in the CONTROL.

In order to separate externally forced variability from internal variability and to study transient adjustment processes, an ensemble of 30 integrations, each 3 months long starting from 1st June with daily outputs, differing only in their initial conditions, is performed for each experiment (e.g., Dong et al. 2014). The same 30 sets of initial conditions are used for each experiment. June 1-30 from the 5th year of a spin-up integration are taken as 30 different June 1 initial conditions in the 30 ensemble integrations. The spin-up integration is forced with climatological SST and sea ice, and with well mixed greenhouse gases concentrations and all species of aerosol emissions at 2000 values. The response to Asian and European sulphur dioxide emissions is estimated as the difference between the ensemble means of the CONTROL and NO-ASIA experiments, and

Table 1 Summary of numerical experiments

Experiments Boundary conditions
Transient experiments (for June, July, and August)

\section{CONTROL Monthly climatological SST and sea ice averaged over the period of 1986-2005 using HadISST (Rayner et al. 2003). Sulphur dioxide, soot, biogenic aerosols, biomass-burning, fossil fuels organic carbon at 2000 emissions. Greenhouse gases concentrations at 2000. No natural forcing variation (e.g., solar, volcanic)}

NO-ASIA As in CONTROL, but without anthropogenic sulphur dioxide emissions over Asia NO-EUROPE As in CONTROL, but without anthropogenic sulphur dioxide emissions over Europe
30 members

30 members

30 members 
the CONTROL and NO-EUROPE experiments, respectively. The ensemble mean across 30 members to a large extent removes the model's internal variability and allows for an assessment of the daily adjustment of the atmospheric circulation and land surface processes.

\subsection{Model climate over East Asia}

In this section some climatological features of the CONTROL experiment are compared with observed features. Figure $2 \mathrm{a}, \mathrm{b}$ shows the observed rainfall based on GPCP (Adler et al. 2003), sea level pressure (SLP) of HadSLP2 (Allan and Ansell 2006) and $850 \mathrm{hPa}$ wind distribution based on NCEP reanalysis (Kalnay et al. 1996), whereas Fig. 2c, d shows the corresponding model climatologies.

The model reproduces the spatial pattern of the East Asian summer climate fairly well (Fig. 2), suggesting that it is appropriate for use in the investigation of the response of the EASM to anthropogenic sulphate aerosols. In observations, the existence of the subtropical anticyclone over the North Pacific causes south-westerlies from the Indian Ocean and easterlies from the tropical Pacific Ocean to converge around the Philippines, becoming a strong southerly (Fig. 2b). This southerly flow transports a large amount of water vapor into East Asia. The anticyclonic circulation in the subtropics over the WNP and south-westerlies over eastern China, Korea and Japan along the western and northern fringes of this anticyclonic circulation are reasonably well reproduced in the model (Fig. 2d). However, the westerly from the Indian Ocean is stronger over the Philippines and it extends too far east into the WNP. The monsoon trough also extends too far to the east, and the southerly from the South China Sea is relatively weak in the model simulation (Fig. 2d). The weaker southerly in the model is associated with a weak subtropical high over the WNP. The stronger convergence over the Philippines and the tropical WNP in model is also consistent with stronger local rainfall (Fig. 2c).

Compared to observations (Fig. 2a), the model simulation shows a relative lack of precipitation over central India, the Western Ghats, and an extensive area over the western Bay of Bengal. It overestimates precipitation over the western equatorial Indian Ocean and the Himalayan foothills (Fig. 2c). Convection tends to be favoured over these latter regions due to the large availability of moisture and heat over the equatorial Indian Ocean and the orographic forcing as the low-level monsoon flow hits the Himalayan foothills respectively. This excessive equatorial Indian Ocean rainfall appears to be an inherent feature of the Met Office Unified model, with preferential model convection over areas with large amounts of available heat and moisture (Martin et al. 2010). This bias is also found in other versions of the Met Office Hadley Centre Global Environmental Model (Levine and Turner 2012; Guo et al. 2013). Despite these deficiencies, the simulated precipitation over East Asia compares fairly well with observations with an area averaged model precipitation of $2.99 \mathrm{~mm}^{-1 a y}{ }^{-1}$ over North China $\left(35^{\circ} \mathrm{N}-45^{\circ} \mathrm{N}, 100^{\circ} \mathrm{E}-125^{\circ} \mathrm{E}\right)$ and $8.93 \mathrm{~mm} \mathrm{day}^{-1}$ over South China $\left(22.5^{\circ} \mathrm{N}-32.5^{\circ} \mathrm{N}\right.$, $100^{\circ} \mathrm{E}-120^{\circ} \mathrm{E}$ ), in comparison with area averaged values of 2.70 and $6.58 \mathrm{~mm} \mathrm{day}^{-1}$ in observations (Fig. 2a, c).

\subsection{Observed trends over East Asia}

Linear trends in precipitation (CRUTS3.21, Harris et al. 2014), SLP (HadSLP2, Allan and Ansell 2006) and $850 \mathrm{hPa}$ winds (NCEP/NCAR reanalysis, Kalnay et al. 1996) for 1950-2012 are shown in Fig. 2e, f. The circulation trends are characterized by positive SLP anomalies $(0.8-1.6 \mathrm{hPa})$ over East Asia, being associated with anomalous northeasterlies along the east coast of Asia and weakened cross-equatorial flow from Southeast Asia, indicating a weakening of the EASM. Associated with these circulation anomalies is a dipole pattern of precipitation trends over East Asia with a decrease of $0.2-0.8 \mathrm{~mm} \mathrm{day}^{-1}$ over North China and an increase of $0.2-1.6 \mathrm{~mm} \mathrm{day}^{-1}$ over South China. The area averaged decrease over North China $\left(35^{\circ} \mathrm{N}-45^{\circ} \mathrm{N}, 100^{\circ} \mathrm{E}-125^{\circ} \mathrm{E}\right)$ is $0.33 \mathrm{~mm} \mathrm{day}{ }^{-1}$ and the area averaged increase over South China $\left(22.5^{\circ} \mathrm{N}-32.5^{\circ} \mathrm{N}\right.$, $100^{\circ} \mathrm{E}-120^{\circ} \mathrm{E}$ ) is $0.29 \mathrm{~mm} \mathrm{day}^{-1}$ and this is the SFND pattern revealed in many previous studies (e.g. Ding et al. 2008, 2009; Zhao et al. 2010; Wang et al. 2013).

\section{Seasonal mean responses to local and non-local sulphur dioxide emissions}

\subsection{Seasonal mean changes of aerosol burden}

The June, July, and August mean changes in aerosol burdens in response to Asian and European sulphur dioxide emissions are illustrated in Fig. 3. Asian emissions lead to localized increases in sulphate burden over the emission area (Fig. 3a). The downstream increases over the WNP are similar to the sulphate burden changes seen between present day and preindustrial conditions in the GISS model (e.g. Bauer and Menon 2012). The increased sulphate burden results in a 60-80\% increase in CDNC (Fig. 3c) and a 10-20\% decrease in CDER over the emission region (Fig. 3e), and a 10-20\% increase in CDNC and a 2.5-5\% decrease in CDER downstream over the WNP.

European emissions induce large increases in sulphate burden not only over Europe, but also downstream over some parts of Asia, Africa, and the tropical Atlantic Ocean (Fig. 3b). Associated with these increases in sulphate burden are increases in CDNC by more than $80 \%$ and decreases in CDER by $10-20 \%$ over Europe and the 
(a) Precipitation in JJA (GPCP)
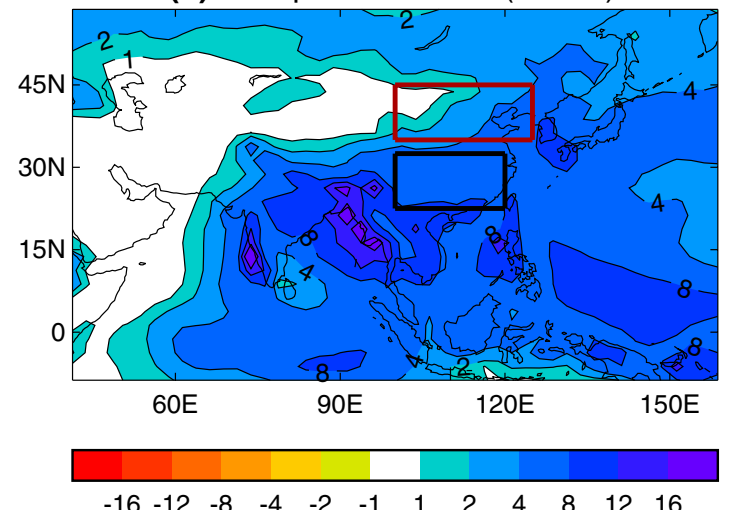

(c) Precipitation in JJA (HadGEM2-ES)
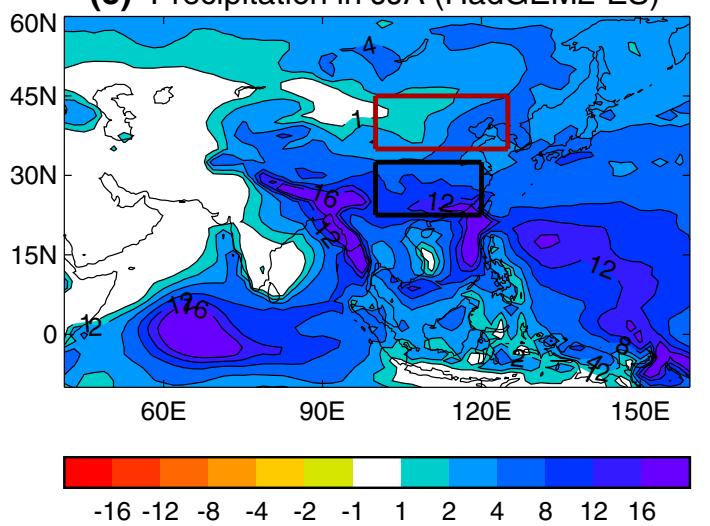

(e) precipitation trend (1950-2012)

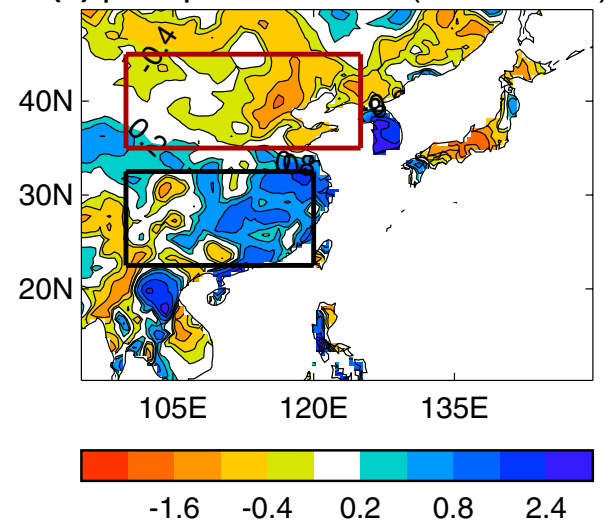

Fig. 2 The spatial patterns of JJA climatology for precipitation $\left(\mathrm{mm} \mathrm{day}{ }^{-1}\right)$, SLP $(\mathrm{hPa})$ and $850 \mathrm{hPa}$ winds $\left(\mathrm{m} \mathrm{s}^{-1}\right)$ in observations $(\mathbf{a}, \mathbf{b})$ and in the model CONTROL experiment $(\mathbf{c}, \mathbf{d})$. e Linear trends in precipitation for the period 1950-2012 based on CRUTS3.21 data

Mediterranean, 10-20\% increases in CDNC over the tropical Atlantic and African monsoon region, the Arabian Sea, south and southeastern Asia, and the WNP and decreases in CDER by 2.5-10 \% (Fig. 3d, f). The changes over south Asia and the WNP are mainly due to advection there by westerly monsoon circulation. (b) $850 \mathrm{hPa}$ wind and SLP in JJA (Obs)

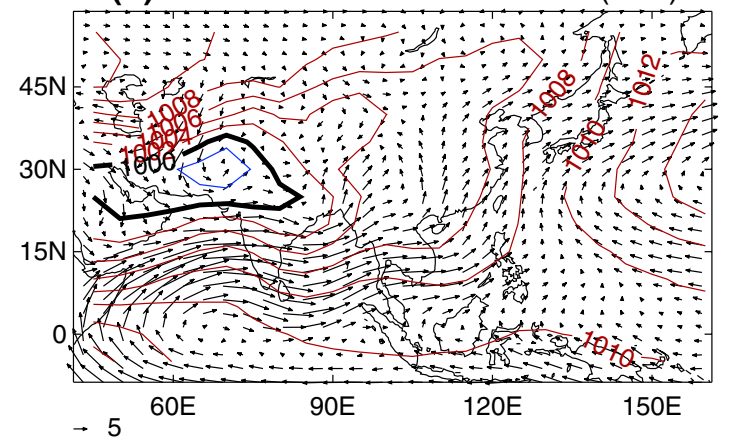

(d) $850 \mathrm{hPa}$ wind and SLP in JJA (HadGEM2-ES)



(f) SLP and $850 \mathrm{hPa}$ wind trend (1950-2012)

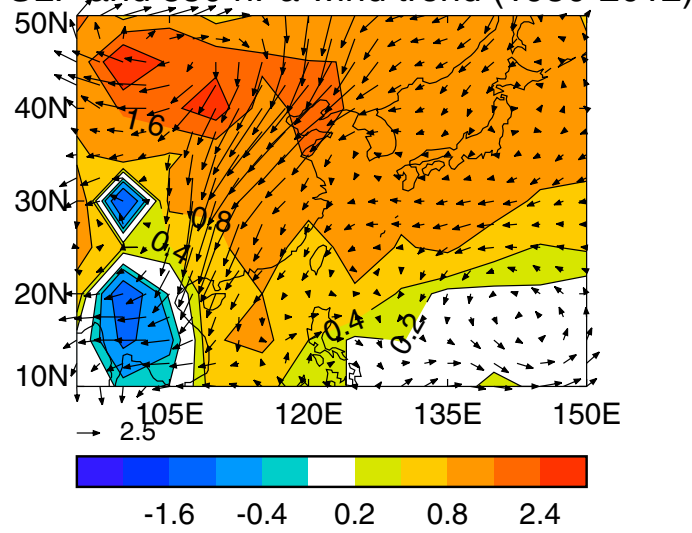

set and $\mathbf{f}$ linear trends in SLP (hPa, HadSLPr2) and $850 \mathrm{hPa}$ wind $\left(\mathrm{m} \mathrm{s}^{-1}\right)$ of NCEP reanalysis. The thick red and black boxes in (a), (c), and (e) highlight North China and South China where area averaged precipitation indices are calculated

\subsection{Seasonal mean responses of the EASM and precipitation}

The seasonal mean changes in surface air temperature (SAT), SLP, $850 \mathrm{hPa}$ winds, and precipitation in response to Asian and European sulphur dioxide emissions are 
(a) Sulphate burden in JJA (Asia)

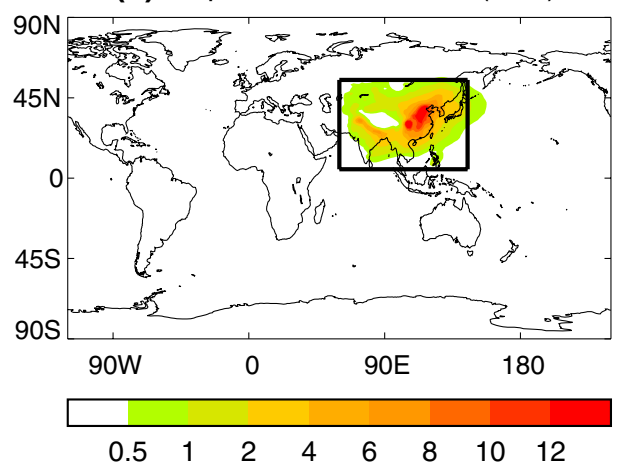

(c) CDNC in JJA (Asia)

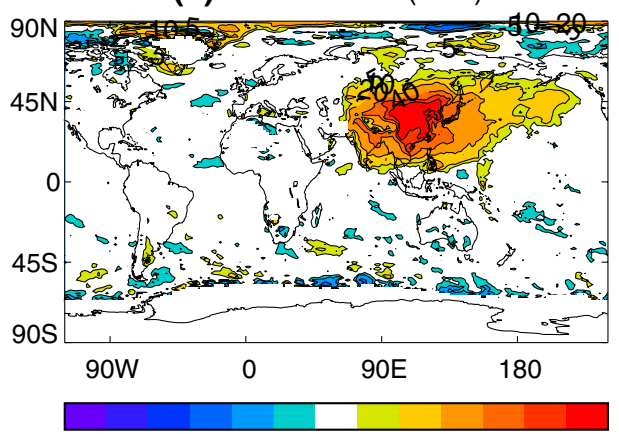

$-80-60-40-20-10-551020406080$

(e) CDER in JJA (Asia)

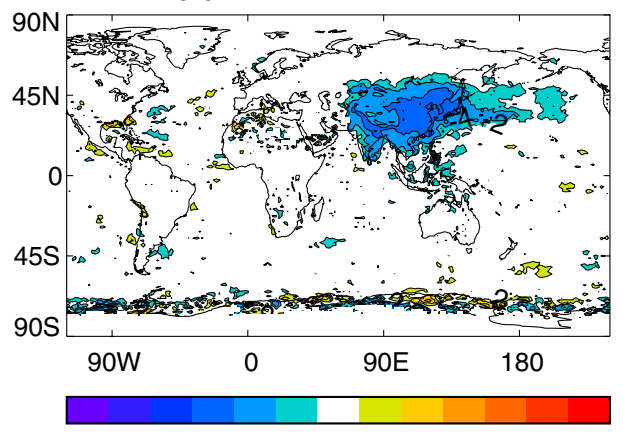

$\begin{array}{llllllllll}-32-24-16 & -8 & -4 & -2 & 2 & 4 & 8 & 16 & 24 & 32\end{array}$

Fig. 3 The spatial patterns of $\mathbf{a}, \mathbf{b}$ changes in sulphate aerosol burden $\left(\mathrm{mg} \mathrm{m}^{-2}\right), \mathbf{c}, \mathbf{d}$ percentage changes in cloud droplet numbers concentration (CDNC), and e, f percentage changes in cloud droplet effec-

illustrated in Fig. 4. Asian emissions lead to a decrease in SAT $\left(\sim 0.2-0.4{ }^{\circ} \mathrm{C}\right)$ over a large area of Asia, accompanied by high pressure anomalies locally (Fig. 4c). Asian emissions also lead to anomalous low pressure over the WNP (Fig. 4c). This dipole pattern of SLP anomalies is opposite to the summer mean pattern, indicating a weakening of the land-sea pressure gradient. This is associated with anomalous north-easterlies along the eastern coast of East Asia (Fig. 4c), indicating a weakening of summer climatological south-westerlies, which results in a decrease

(b) Sulphate burden in JJA (Europe)

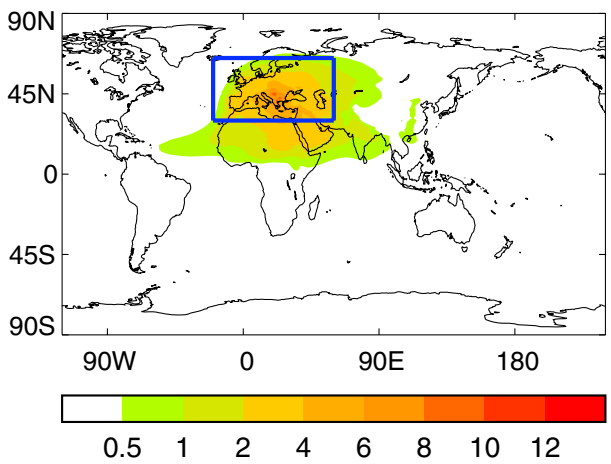

(d) CDNC in JJA (Europe)

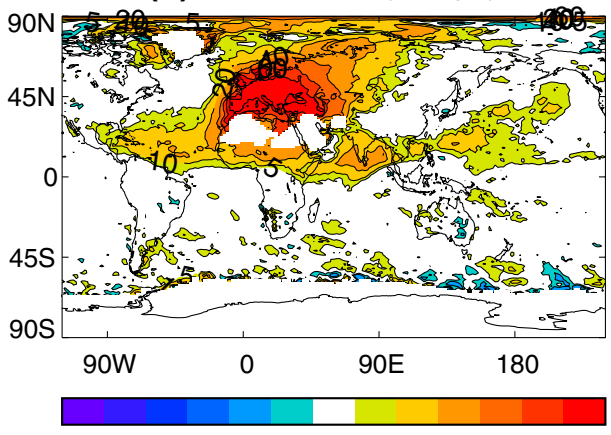

$-80-60-40-20-10-5 \quad 5 \quad 1020406080$

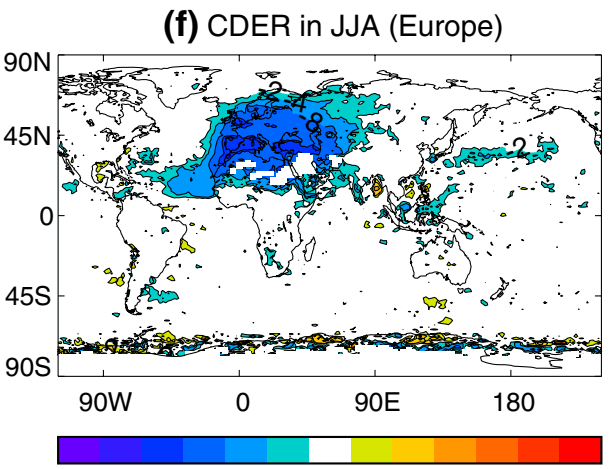

$-32-24-16-8 \quad-4 \quad-2 \quad 2 \quad 4 \quad 8 \quad 162432$

tive radius (CDER) in response to Asian and European sulphur dioxide emissions in June, July, and August. The black and blue boxes in (a, b) highlight Asia and Europe where emissions are perturbed

$\left(\sim 0.4-1.2 \mathrm{~mm} \mathrm{day}^{-1}\right)$ in precipitation over East Asia, and an increase to the south and over the WNP (Fig. 4e).

Despite only inducing a small change in the sulphate burden over Asia, European emissions also lead to a significant surface cooling over Asia and a dipole pattern of SLP anomalies, characterized by an anomalous high over Asia and an anomalous low over the WNP. This is similar in structure to the dipole pattern of SLP anomalies that results from Asian emissions, but the magnitude of the anomalous low over the WNP in response to European emissions 
(a) SAT (Asia)

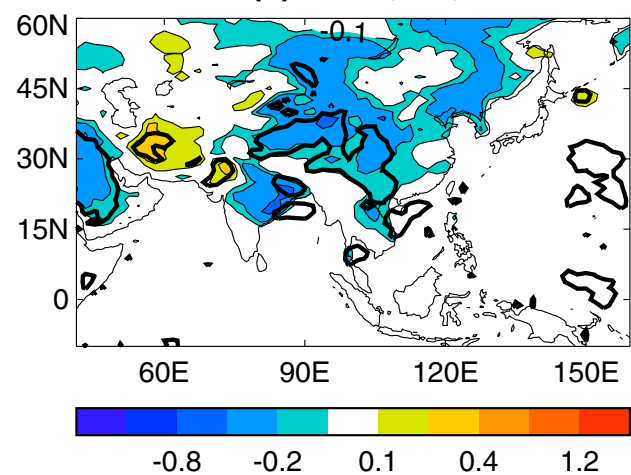

(c) SLP and $850 \mathrm{hPa}$ wind (Asia)

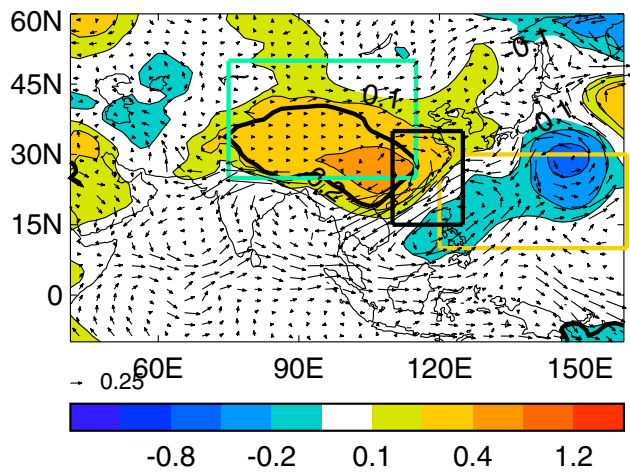

(e) precipitation (Asia)

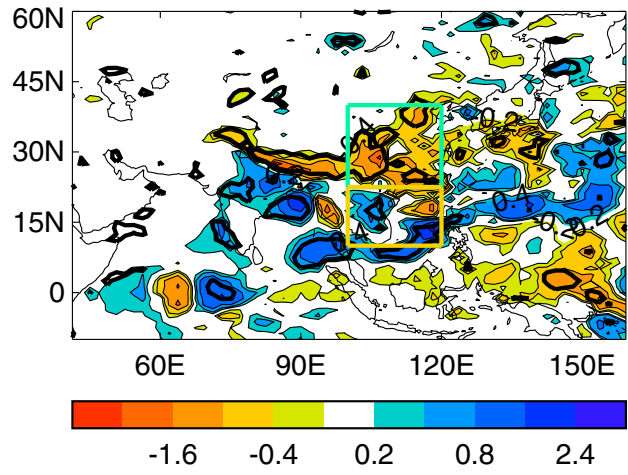

Fig. 4 The spatial patterns of changes in surface air temperature $\left(\mathrm{SAT},{ }^{\circ} \mathrm{C}\right)$, SLP $(\mathrm{hPa})$ and $850 \mathrm{hPa}$ wind $\left(\mathrm{m} \mathrm{s}^{-1}\right)$, and precipitation $\left(\mathrm{mm} \mathrm{day}{ }^{-1}\right)$ in response to Asian and European sulphur dioxide emissions in June, July, and August. Thick black lines highlight regions

is larger. This dipole pattern of SLP anomalies is again associated with anomalous north-easterlies along the coast of East Asia (Fig. 4d), indicating a weakening of summer south-westerlies. Associated with these circulation anomalies are a decrease $\left(\sim 0.4-0.8 \mathrm{~mm} \mathrm{day}^{-1}\right)$ in precipitation over East Asia and an increase $\left(0.4-1.2 \mathrm{~mm} \mathrm{day}^{-1}\right)$ to the south and over the WNP (Fig. 4f). The main features of the weakening EASM circulation induced by both Asian and European emissions are anomalous high pressure over Asia (b) SAT (Europe)

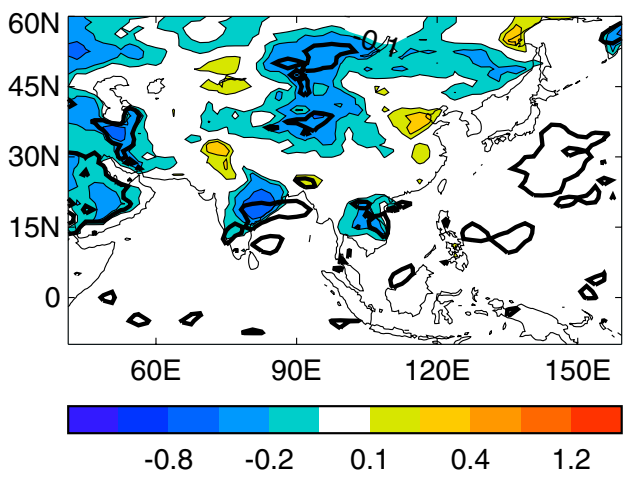

(d) SLP and $850 \mathrm{hPa}$ wind (Europe)

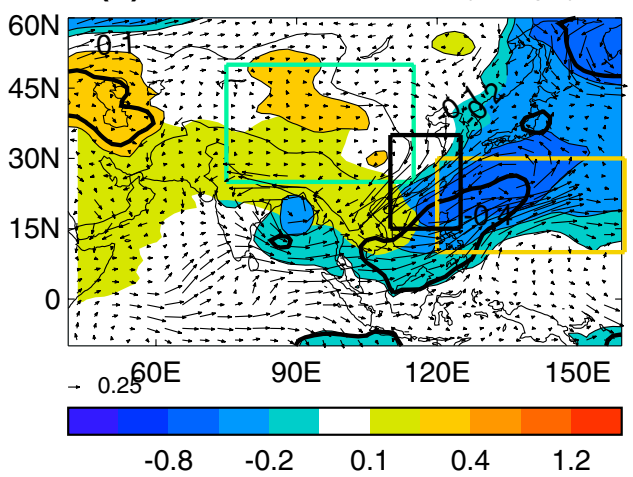

(f) precipitation (Europe)

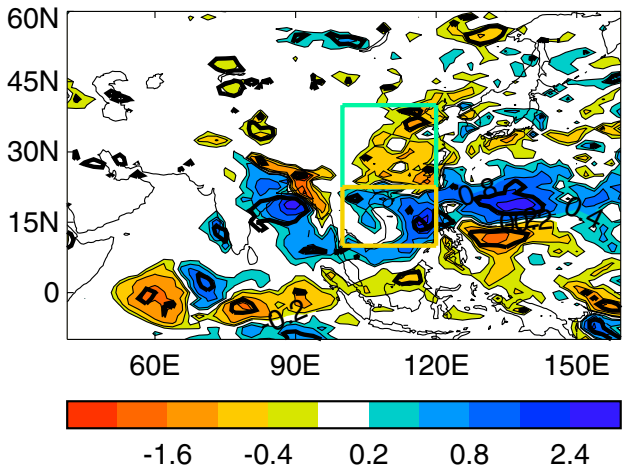

where the changes are statistically significant at the $90 \%$ confidence level using a two-tailed Student's $t$ test. The thick colour boxes highlight regions where some indices are illustrated in Figs. 5 and 6

and anomalous low pressure over the WNP. The results suggest a remote response of the EASM to European emissions and indicate a preferred response of the EASM to local and non-local anthropogenic sulphur dioxide emissions. Note that, in contrast to the response to Asian emissions, changes in sulphate burden, CDNC and CDER in response to European emissions are very small over Asia (Fig. 3); this contrast implies that different processes are involved in producing the climate impacts. 


\section{Time evolution of the East Asian summer monsoon responses}

Section 3.2 indicated that key features of the responses to both Asian and European sulphur dioxide emissions are: anomalous high pressure over Asia and anomalous low pressure over the WNP, associated with anomalous northeasterlies along the eastern coast of East Asia, indicating a weakening south-westerly EASM circulation. Interestingly this pattern is similar to the trends seen in observations (Fig. 2f). We now consider in more detail the mechanisms that lead to the weakened EASM by examining the time evolution of the response.

\subsection{Fast adjustments}

The time evolutions (5 day mean) of some EASM indices in response to a sudden change in regional sulphur dioxide emissions are illustrated in Fig. 5. These transient evolutions reveal that significant changes in the EASM occur from about day 40-50 onward, in response to both Asian and European emissions. The changes are characterized by a significant weakening of the tropospheric temperature difference between Asia and the WNP (Fig. 5a), weakening SLP difference between the WNP and Asia (Fig. 5b), and reduction in summer monsoon meridional wind (Fig. 5c). Associated with these changes in land-sea temperature contrast and circulation is a decrease in precipitation over East Asia (Fig. 5d), and an increase to the south and over the WNP (Fig. 5e).

Figures 6 and 7 show the development of the atmosphere and land surface responses over Asia (Note area averaged responses over Asia for a selection of variables for the 1-20 and 41-90 day means are given in Table 2). Aerosol-radiation and aerosol-cloud interactions in response to Asian emissions lead to a rapid increase in top of atmosphere (TOA) upward SW radiation (not shown) and therefore a decrease in TOA clear sky net SW and TOA net SW (Fig. 6c, d; Table 2) during the first 20 days. Changes in atmospheric SW absorption are very small (Table 2). As a result, the decrease in surface net $\mathrm{SW}$ is similar to the change at TOA (Fig. 6d, e; Table 2). The reduction in surface net SW radiation is partly compensated by a decrease in upward turbulent heat fluxes (Fig. 6g; Table 2), so there
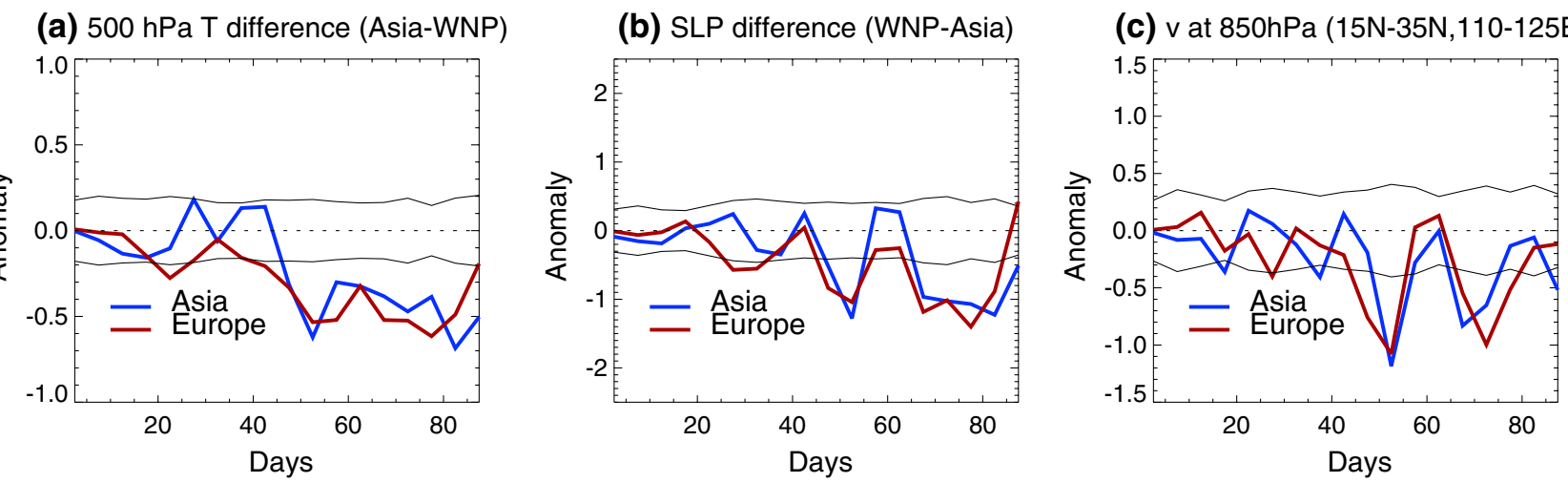

(d) Precipitation (22.5-40N, 100E-120E)

(e) Precipitation (10-22.5N, 100E-120E)
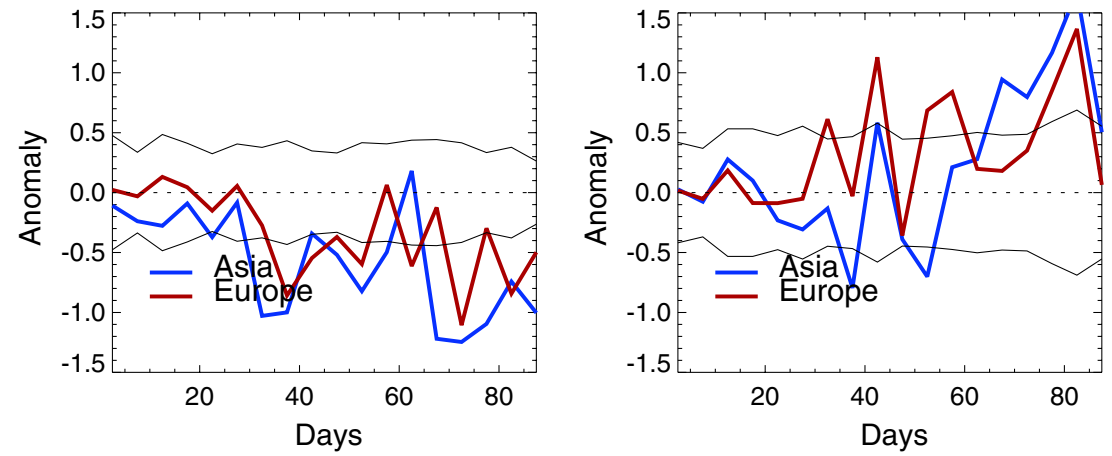

Fig. 5 The time evolutions of 5 day averaged ensemble mean changes of EASM indices induced by Asian and European sulphur dioxide emissions in June, July, and August. a $500 \mathrm{hPa}$ temperature difference $\left({ }^{\circ} \mathrm{C}\right.$ ) between WNP and Asia (yellow and green boxes in Fig. 4c). b SLP difference (hPa), c meridional wind $\left(\mathrm{m} \mathrm{s}^{-1}\right.$ ) over East coast of Asia (black box in Fig. 4c). d, e Precipitation $\left(\mathrm{mm} \mathrm{day}^{-1}\right.$ ) over green and yellow boxes shown in Fig. 4e. The thin lines show the $\mathrm{N}^{-1 / 2}$ of internal standard deviation in the GLOBAL experiment with the number of integrations $\mathrm{N}=30$ 
(a) Sulphate AOD at 0.55 um

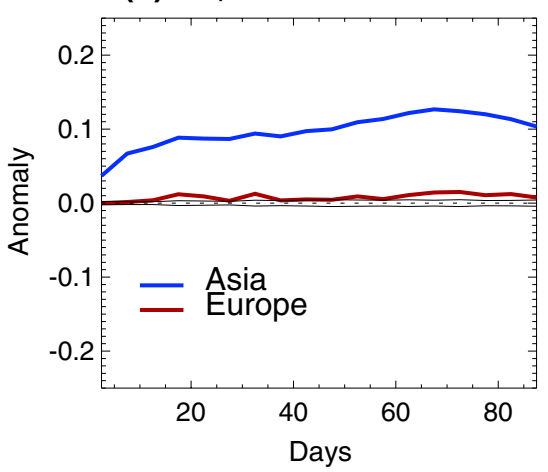

(d) TOA SW

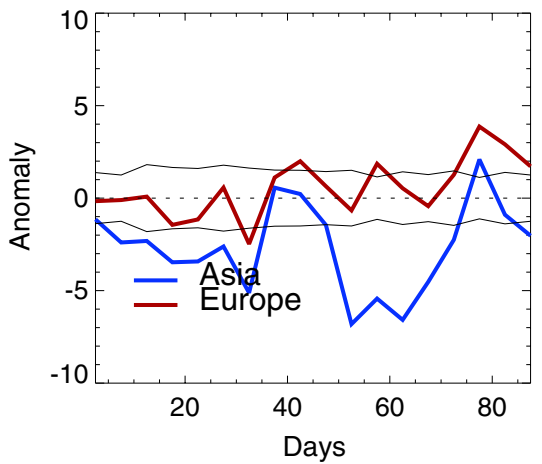

(g) Sensible \& latent heat flux

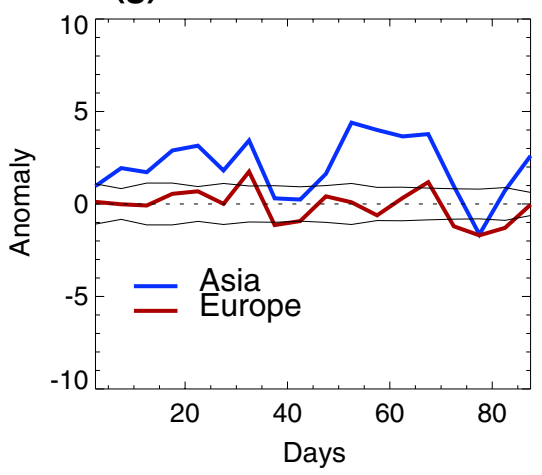

(b) Water vapor

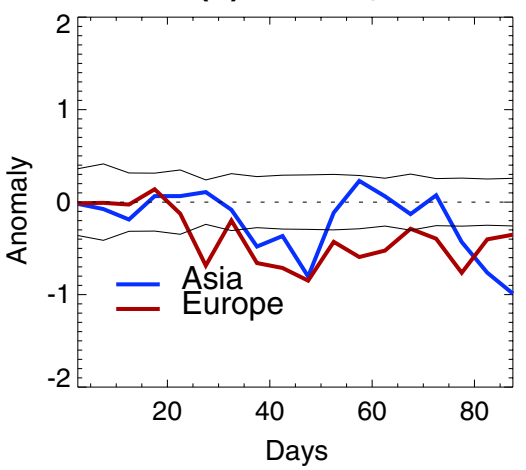

(e) surface SW

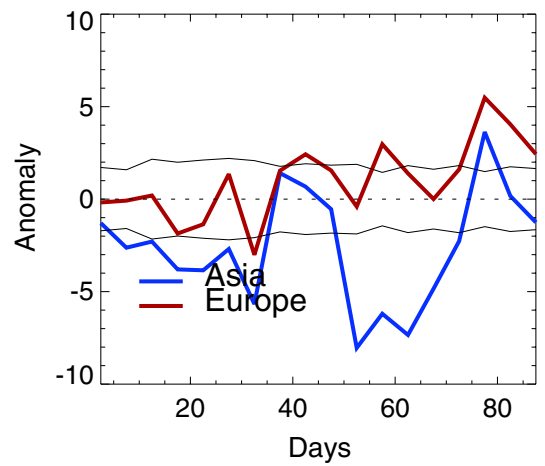

(h) SAT

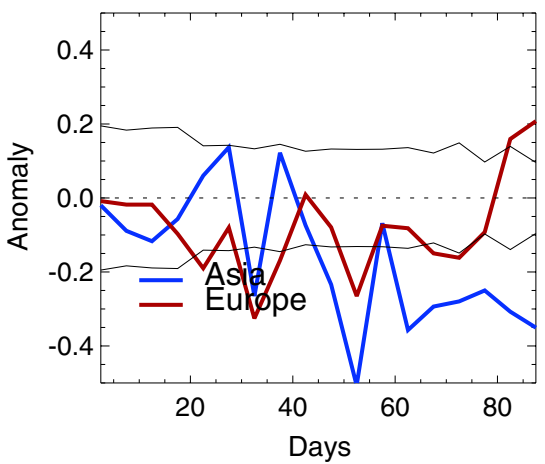

(c) TOA clear sky SW



(f) surface LW

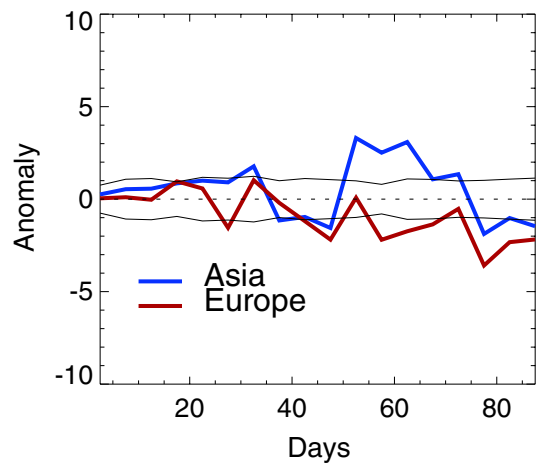

(i) $500 \mathrm{hPa}$ temperature

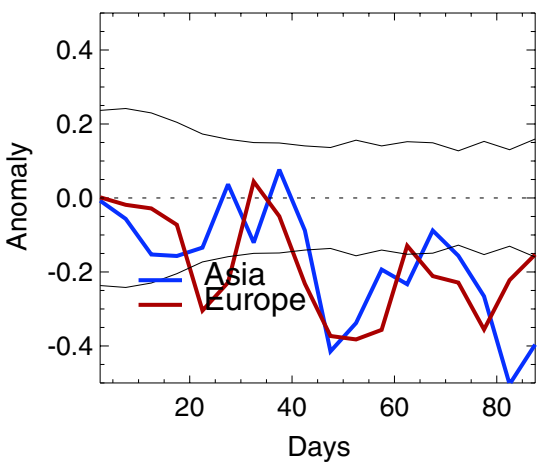

Fig. 6 The time evolutions of 5 day averaged ensemble mean changes over Asia $\left(25^{\circ} \mathrm{N}-50^{\circ} \mathrm{N}, 75^{\circ} \mathrm{E}-115^{\circ} \mathrm{E}\right.$, green box in Fig. 4c) induced by Asian and European sulphur dioxide emissions in June, July, and August. a Sulphate AOD at $0.55 \mu \mathrm{m}, \mathbf{b}$ column integrated water vapor $\left(\mathrm{kg} \mathrm{m}^{-2}\right)$, c top of atmosphere (TOA) clear sky shortwave radiation (SW), d TOA SW, e surface SW, f surface LW, g sur- face sensible and latent heat flux, $\mathbf{h}$ surface air temperature (SAT, $\left.{ }^{\circ} \mathrm{C}\right)$, and $\mathbf{i}$ air temperature at $500 \mathrm{hPa}$. Radiation and fluxes are in $\mathrm{W} \mathrm{m}^{-2}$ and positive values mean downward. Radiation is the net component. The thin lines show the $\mathrm{N}^{-1 / 2}$ of internal standard deviation in the GLOBAL experiment with the number of integrations $\mathrm{N}=30$

After day 20, significant changes over Asia in column integrated water vapor (Fig. 6b), tropospheric temperature and specific humidity (Fig. 7), occur in response to both Asian and European emissions. A decrease in column integrated water vapor in response to European emissions especially shows a persistent signal from day 25 onward. This decrease in water vapor, associated with a decrease in cloud cover (not shown), leads to substantial changes in the

(Fig. 6e, f; Table 2) are very small. 
Fig. 7 The time evolutions of 5 day averaged ensemble mean changes with height over Asia $\left(25^{\circ} \mathrm{N}-50^{\circ} \mathrm{N}, 75^{\circ} \mathrm{E}-115^{\circ} \mathrm{E}\right.$, green box in Fig. 4c) induced by Asian and European sulphur dioxide emissions in June, July, and August. a, b For temperature $\left({ }^{\circ} \mathrm{C}\right)$, and $\mathbf{c}, \mathbf{d}$ for percentage changes in specific humidity relative to the CONTROL experiment (\%). Thick black lines highlight regions where the changes are statistically significant at the $90 \%$ confidence level using a two-tailed Student $t$ test

Table 2 Area averaged responses for various variables for the (1-20) and (41-90) day means over Asia $\left(25-50^{\circ} \mathrm{N}\right.$, $\left.75-115^{\circ} \mathrm{E}\right)$ (a) Temperature (Asia)

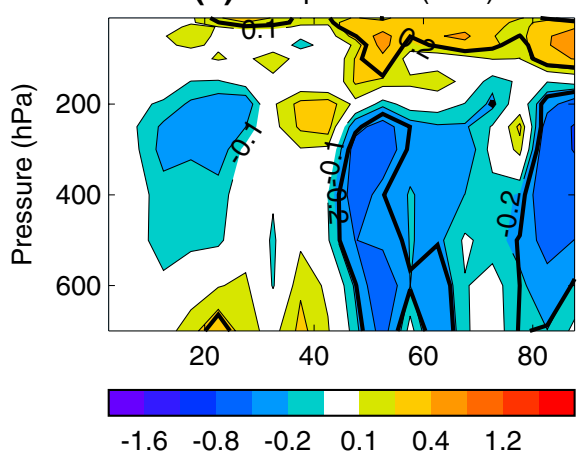

(c) Humidity \% (Asia)

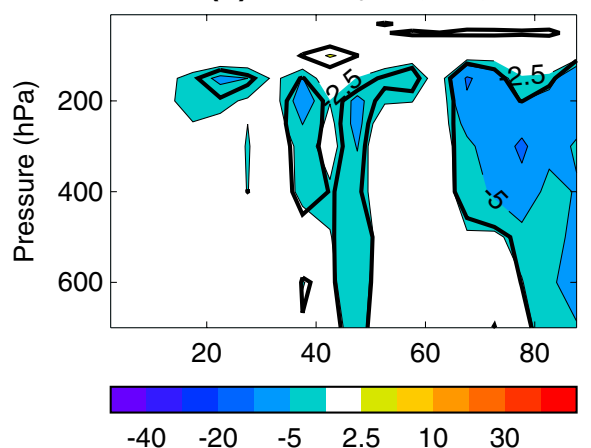

(b) Temperature (Europe)



(d) Humidity \% (Europe)

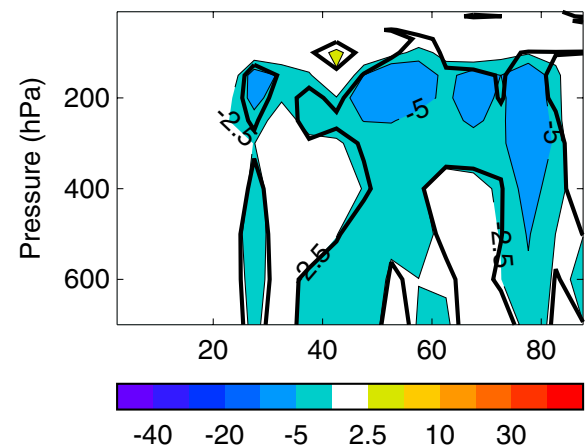

\begin{tabular}{|c|c|c|c|c|}
\hline & \multicolumn{2}{|l|}{ Asian impact } & \multicolumn{2}{|c|}{ European impact } \\
\hline & Day $(1-20)$ & Day $(41-90)$ & Day $(1-20)$ & Day (41-90) \\
\hline Sulphate AOD at $0.55 \mu \mathrm{m}$ & 0.07 & 0.11 & 0.004 & 0.01 \\
\hline Column integrated water vapor $\left(\mathrm{kg} \mathrm{m}^{-2}\right)$ & -0.054 & -0.32 & 0.023 & -0.53 \\
\hline High cloud cover $(\%)$ & -0.12 & -0.81 & -0.10 & -0.62 \\
\hline Medium cloud cover $(\%)$ & 0.09 & -0.34 & 0.09 & -0.81 \\
\hline Low cloud cover $(\%)$ & 0.38 & 0.18 & 0.14 & -0.67 \\
\hline Surface latent heat $\left(\mathrm{W} \mathrm{m}^{-2}\right)$ & 1.476 & 1.478 & 0.21 & 0.60 \\
\hline Surface sensible heat $\left(\mathrm{W} \mathrm{m}^{-2}\right)$ & 0.40 & 0.56 & -0.07 & -0.98 \\
\hline \multirow[t]{2}{*}{ Surface total heat flux $\left(\mathrm{W} \mathrm{m}^{-2}\right)$} & -0.07 & -0.12 & -0.07 & 0.05 \\
\hline & SW, LW & SW, LW & SW, LW & SW, LW \\
\hline TOA $\left(\mathrm{W} \mathrm{m}^{-2}\right)$ & $-2.33,0.11$ & $-2.77,-0.45$ & $-0.41,0.14$ & $1.37,-1.07$ \\
\hline TOA clear sky $\left(\mathrm{W} \mathrm{m}^{-2}\right)$ & $-1.92,0.21$ & $-3.08,0.38$ & $-0.15,0.16$ & $-0.36,-0.45$ \\
\hline Cloud radiative effect (CRE) $\left(\mathrm{W} \mathrm{m}^{-2}\right)$ & $-0.41,-0.10$ & $0.32,-0.83$ & $-0.26,-0.02$ & $1.73,-0.62$ \\
\hline Surface $\left(\mathrm{W} \mathrm{m}^{-2}\right)$ & $-2.50,0.55$ & $-2.60,0.44$ & $-0.48,0.27$ & $2.15,-1.72$ \\
\hline Surface clear sky $\left(\mathrm{W} \mathrm{m}^{-2}\right)$ & $-1.92,0.31$ & $-2.78,0.34$ & $-0.20,0.16$ & $0.21,-1.27$ \\
\hline Atm: TOA-surface $\left(\mathrm{W} \mathrm{m}^{-2}\right)$ & $0.17,-0.44$ & $-0.16,-0.89$ & $0.07,-0.13$ & $-0.78,0.65$ \\
\hline Atm: TOA-surface clear sky $\left(\mathrm{W} \mathrm{m}^{-2}\right)$ & $0.00,-0.10$ & $-0.31,0.05$ & $0.05,0.00$ & $-0.57,0.82$ \\
\hline
\end{tabular}

Radiation and fluxes are positive downwards. Net radiation is shown in all cases surface energy budget (Fig. 6), including an increase in surface net $\mathrm{SW}$ of about $1.0 \mathrm{~W} \mathrm{~m}^{-2}$ and a decrease in surface net LW (Fig. 6e, f).

The EASM is driven by land-sea thermal contrast between the Asian continent and adjacent oceans (e.g.,
Webster 1987; Tao and Chen 1987; Zuo et al. 2012). Not only are changes over the Asian continent important, but also changes over the WNP, as illustrated in Fig. 4 for the seasonal mean changes. Time series of key variables over the WNP are illustrated in Fig. 8. There is hardly 
Fig. 8 The time evolutions of 5 day averaged ensemble mean changes over the WNP $\left(10^{\circ} \mathrm{N}-30^{\circ} \mathrm{N}, 120^{\circ} \mathrm{E}-160^{\circ} \mathrm{E}\right.$, yellow box in Fig. 4c) induced by Asian and European sulphur dioxide emissions in June, July, and August. a-d Height-time evolutions of the change relative to the CONTROL. a, b For temperature change $\left({ }^{\circ} \mathrm{C}\right)$, and $\mathbf{c}, \mathbf{d}$ for percentage changes in specific humidity (\%). e SLP (hPa), f surface latent heat flux ( $\mathrm{W} \mathrm{m}^{-2}$, downward positive), $\mathbf{g}$ high cloud cover (\%), and $\mathbf{h}$ precipitation $\left(\mathrm{mm} \mathrm{day}^{-1}\right)$. Thick black lines in (a-d) highlight regions where the changes are statistically significant at the $90 \%$ confidence level using a two-tailed Student $t$ test. The thin lines in $(\mathbf{e}-\mathbf{h})$ show the $\mathrm{N}^{-1 / 2}$ of internal standard deviation in the GLOBAL experiment with the number of integrations $\mathrm{N}=30$
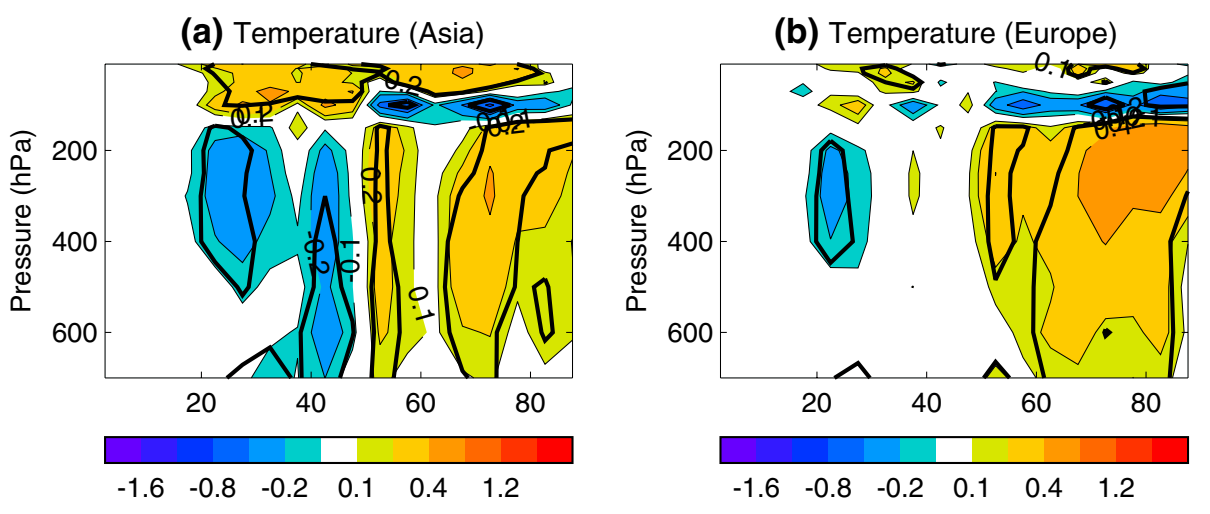

(c) Humidity \% (Asia)

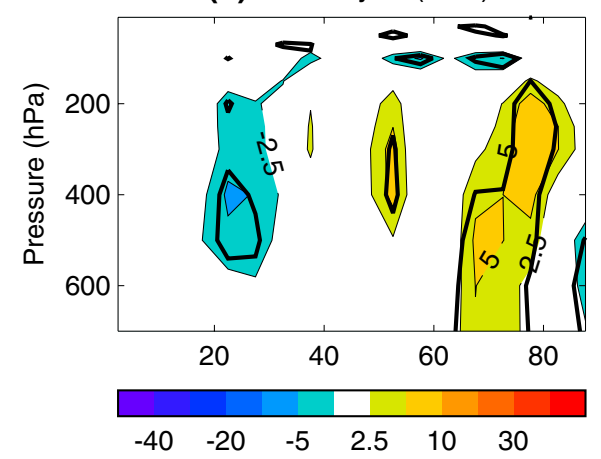

(e) SLP

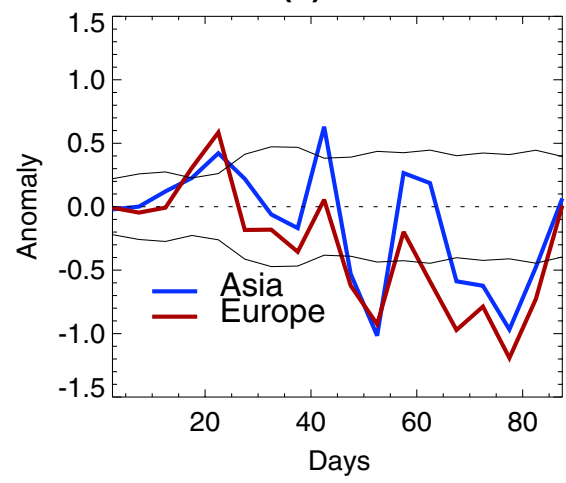

(g) High cloud cover



(d) Humidity \% (Europe)

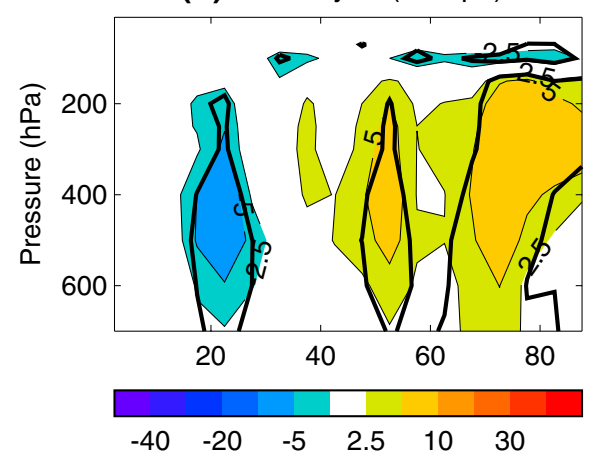

(f) Latent heat flux

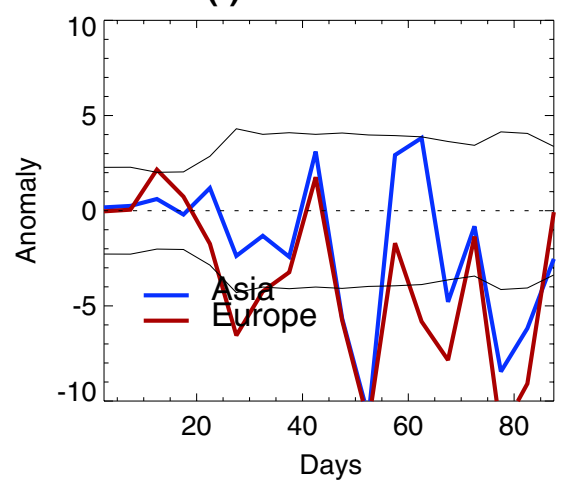

(h) Precipitation

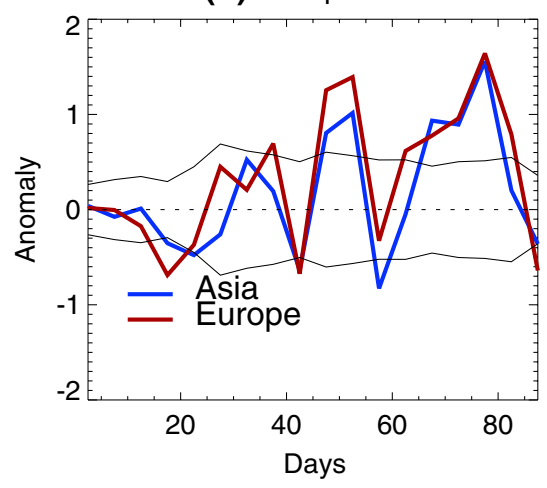

any significant change in either temperature or water vapor in first 20 days in response to either Asian or European emissions (Fig. 8a-d). However, significant—albeit short-lived-changes occur around day 20, characterized by drying and cooling in the free troposphere, associated with anomalous high SLP (Fig. 8e), reduced deep 
(a) SLP and $850 \mathrm{hPa}$ wind in days 16 to 25 (Asia)

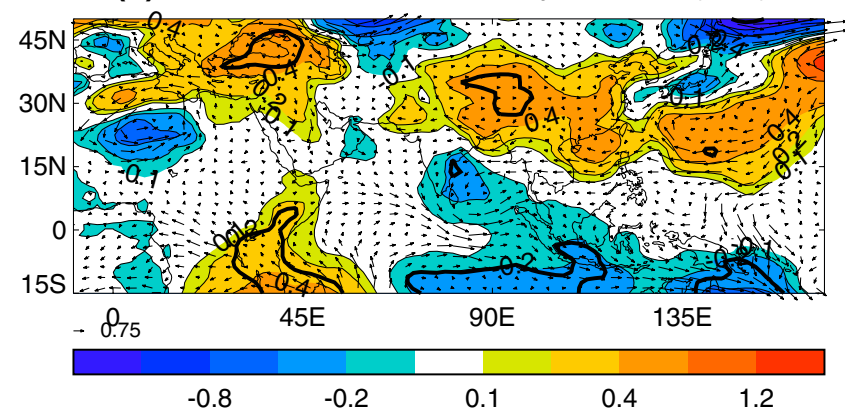

(c) water vapor in days 16 to 25 (Asia)

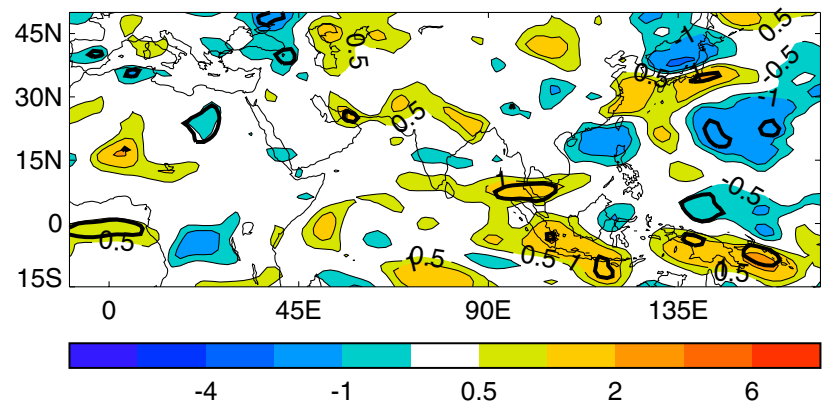

Fig. 9 Days 16-25 mean anomalies in response to Asian and European emissions. a, b SLP (hPa) and $850 \mathrm{hPa}$ wind $\left(\mathrm{m} \mathrm{s}^{-1}\right)$, c, d column integrated water vapor $\left(\mathrm{kg} \mathrm{m}^{-2}\right)$. Thick black lines highlight

convection (Fig. 8g) and precipitation (Fig. 8h). This cooling and drying is associated with a meridional dipole SLP pattern in the eastern hemisphere with positive anomalies around $15^{\circ} \mathrm{N}-30^{\circ} \mathrm{N}$ and negative anomalies around $15^{\circ} \mathrm{S}-10^{\circ} \mathrm{N}$ (Fig. 9a, b) that result in moisture divergence over the WNP and moisture convergence over the tropical Indian Ocean and tropical western Pacific (Fig. 9c, d). Most importantly, the drying and cooling in the free troposphere over the WNP during days 20-40 (Fig. 8a-e) are similar in magnitude to the drying and cooling over Asia (Fig. 7). The changes in the land-sea thermal contrast in the troposphere are therefore small (Fig. 5a, b). As a result, changes in EASM circulation and associated precipitation are small during this period (Fig. 5c).

The phase relationship among different variables over the WNP from days 20 to 40 is interesting. The drying of the atmosphere around day 20 leads to increased upward latent heat flux from days 25-30 (Fig. 8f) due to enhanced evaporation (not shown), leading to a rapid increase in atmospheric water vapour from days 25 to 40 , setting conditions for enhanced convection over the WNP.

As illustrated in Fig. 8, significant changes, opposite in sign to changes during days 20-30, occur over the WNP after about day 40 in response to both Asian and European emissions. These changes are characterized by rapid warming and moistening in the free troposphere (Fig. 8a-d), a (b) SLP and $850 \mathrm{hPa}$ wind in days 16 to 25 (Europe)

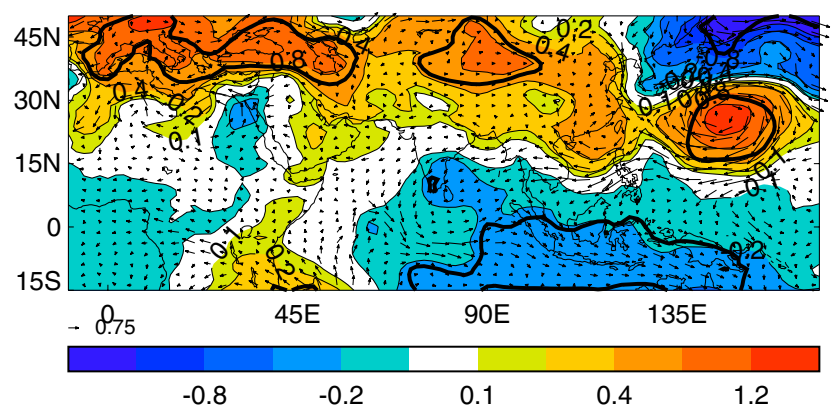

(d) water vapor in days 16 to 25 (Europe)

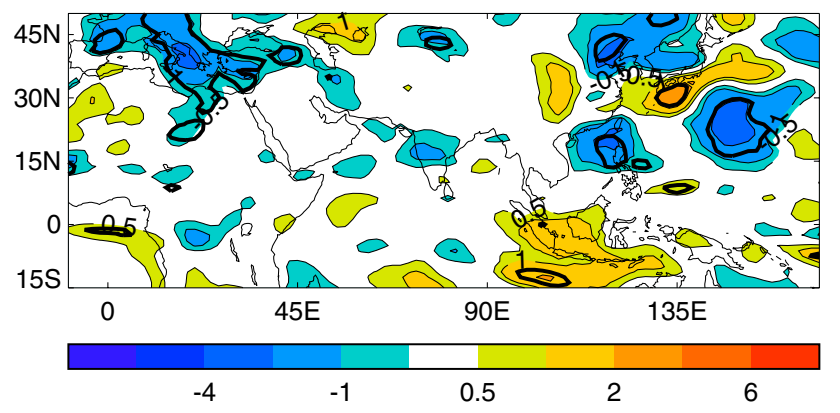

regions where the changes are statistically significant at the $90 \%$ confidence level using a two-tailed Student $t$ test

decrease in SLP (Fig. 8e), an increase in upward latent flux (Fig. 8f), enhanced deep convection (increase in high cloud cover) and precipitation (Fig. 8g, h). These changes over the WNP indicate a strong local coupling among the changes in SLP, local evaporation, tropospheric moistening, convection, and tropospheric warming. The low SLP anomaly leads to enhanced evaporation due to strengthened westerlies, resulting atmospheric moistening, leading to enhanced convection, inducing warming in free troposphere, especially in the upper troposphere. This warming in turn favours further decrease in SLP locally, providing a positive feedback. The warming and moistening over the WNP, together with opposite changes over Asian continent weaken the land-sea thermal contrast, induce larger thermal contrast in the upper troposphere than in the lower troposphere and determine time scales for the significant EASM response. The results suggest an important role of the upper tropospheric land-sea thermal contrast for the response of the EASM, consistent with recent studies (e.g., Bayr and Dommenget 2013, Dai et al. 2013).

Figure 5 also reveals intraseasonal variability (ISV) of the EASM indices in response to either Asian or European emissions. This ISV is mainly associated with the variability over the WNP (Fig. 8), where observations also show large ISV in boreal summer (Wang et al. 2009). This ISV might result from feedbacks between free tropospheric 
(a) Sulphate AOD at 0.55 um

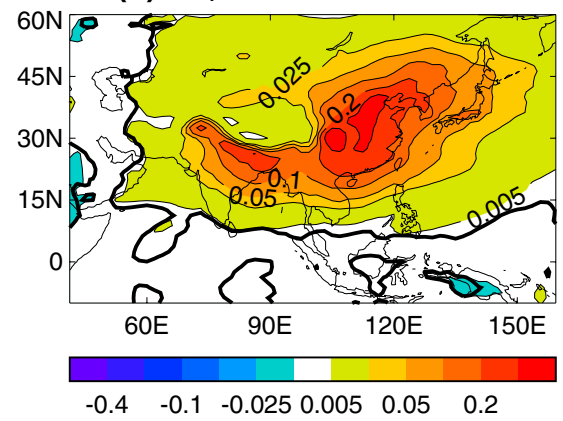

(d) Latent heat

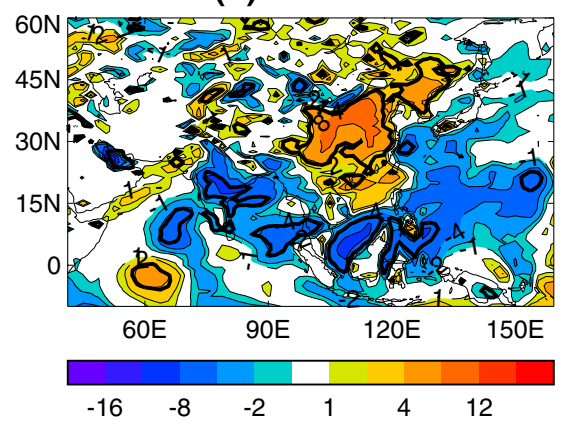

(g) SLP and $850 \mathrm{hPa}$ wind



(b) TOA clear sky SW

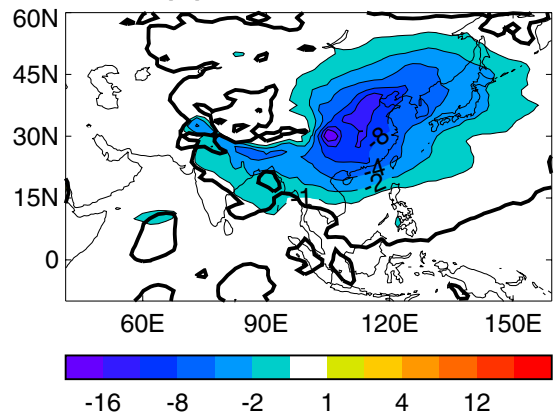

(e) SAT

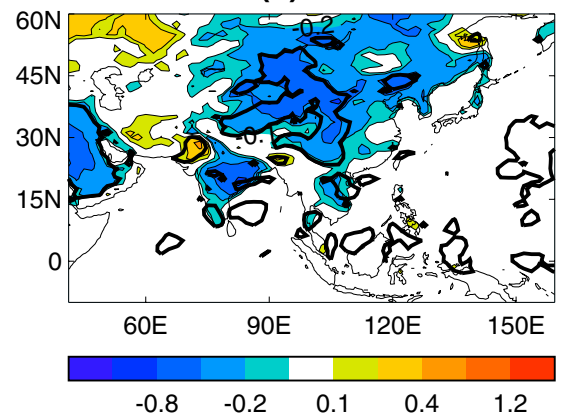

(h) Moisture transport

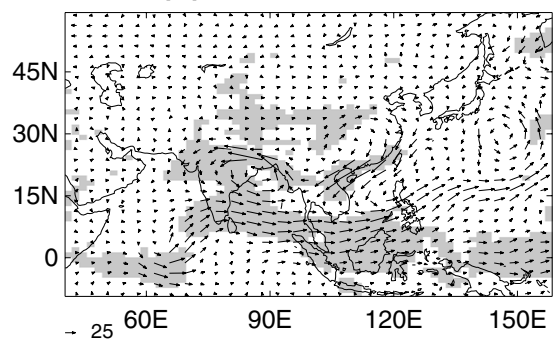

(c) Surface SW

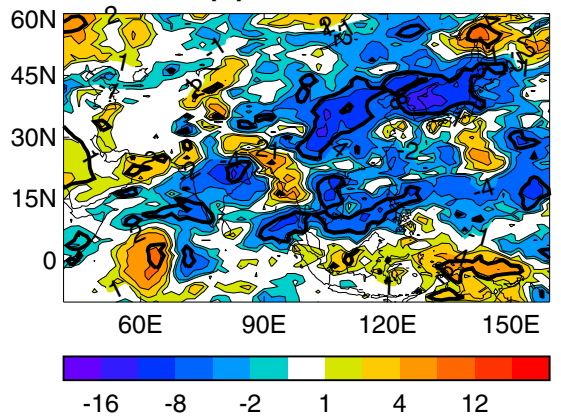

(f) Temperature at $500 \mathrm{hPa}$

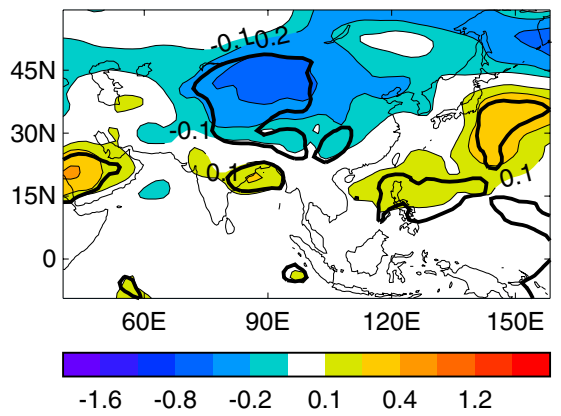

(i) precipitation

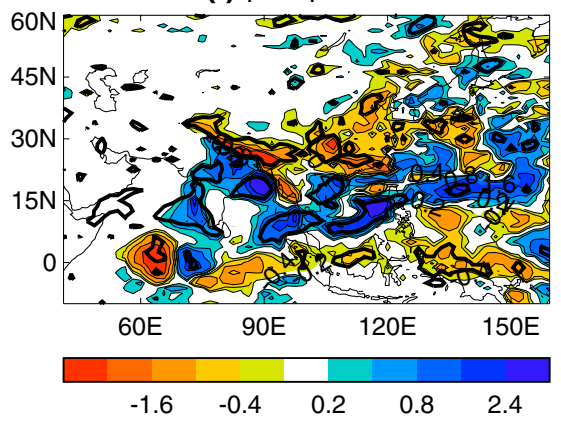

Fig. 10 Days 41-90 mean anomalies in response to Asian emissions. a Sulphate AOD at $0.55 \mu \mathrm{m}, \mathbf{b}$ top of atmosphere (TOA) clear sky SW, c surface SW, d surface latent heat flux, e surface air temperature (SAT, $\left.{ }^{\circ} \mathrm{C}\right)$, f air temperature at $500 \mathrm{hPa}\left({ }^{\circ} \mathrm{C}\right)$, g $\mathrm{SLP}(\mathrm{hPa})$ and $850 \mathrm{hPa}$ wind $\left(\mathrm{m} \mathrm{s}^{-1}\right)$, h vertically integrated water vapor transport $\left(\mathrm{kg} \mathrm{m}^{-1} \mathrm{~s}^{-1}\right)$, and $\mathbf{i}$ precipitation $\left(\mathrm{mm} \mathrm{day}^{-1}\right)$. Radiation and fluxes are in $\mathrm{W} \mathrm{m}^{-2}$ and positive values mean downward. Radiation is the net component. Thick black lines highlight regions where the changes are statistically significant at the $90 \%$ confidence level using a twotailed Student $t$ test moisture and convection (e.g., Grabowski 2006; Wang et al. 2009). As shown in Fig. 8, anomalously low SLP around day 50 over the WNP enhances upward latent heat flux (Fig. 8e, f), leading to tropospheric moistening (Fig. 8c, d), enhancing deep convection (Fig. 8g, h) and atmospheric warming (Fig. 8a, b). The increased precipitation reduces atmospheric moisture that tends to cool the atmosphere and leads to an increase in SLP, leading to oscillation on intraseasonal time scale (e.g., Grabowski 2006; Wang et al. 2009). However, understanding the detailed processes behind the ISV is beyond the scope of this paper. We now focus on the time-mean response during days 41-90, when significant weakening of the EASM occurs in response to both Asian and European emissions. This period dominates the seasonal mean responses.

\subsection{Days 41-90 response to Asian emissions}

The spatial patterns of time mean changes over days 41-90 of some key variables induced by Asian sulphur dioxide emissions are illustrated in Fig. 10 (see also Table 2). Asian emissions lead to localized increases in sulphate AOD over Asia of up to $\sim 0.2$ (Fig. 10a). The increase in direct scattering by the sulphate aerosols themselves, and the related increase in cloud albedo via aerosol cloud interactions leads to a localized decrease in TOA clear sky net SW 
radiation $\left(2-8 \mathrm{~W}^{-2}\right)$ over Asia (Fig. 10b). The changes in surface net $\mathrm{SW}$ radiation show a reduction by $2-6 \mathrm{~W} \mathrm{~m}^{-2}$ (Fig. 10c), which is mainly related to changes in clear sky surface net SW (Table 2).

The reduction of surface net SW radiation over Asia, only part of which is compensated by a decrease in upward latent heat flux (Fig. 10d; Table 2), acts to cool the surface and free troposphere (Fig. 10e, f). Meanwhile, the upward latent heat flux over the WNP and tropical Indian Ocean increases, consistent with enhanced convection and precipitation (Fig. 10i) and the increase in tropospheric air temperature there (Fig. 10f). This distribution of temperature anomalies reduces meridional and zonal land-sea thermal contrasts, and is associated with high SLP anomalies over Asia and low SLP anomalies over the WNP, leading to anomalous northeasterlies over East Asia, weakening EASM (Fig. 10g), anomalous moisture transport divergence over East Asia and convergence to the South (Fig. 10h), and a decrease in precipitation $\left(\sim 0.4-1.6 \mathrm{~mm} \mathrm{day}^{-1}\right)$ over East Asia and an increase over the WNP and tropical Indian Ocean (Fig. 10i). Importantly, results in our study indicate that the warming resulting from the diabatic heating associated with enhanced deep convection over the WNP causes further reductions in the land-sea thermal contrast between Asia and the WNP, providing a positive feedback for the weakened EASM related to the cooling over land.

The patterns of changes in circulation and precipitation in response to Asian anthropogenic sulphur dioxide emissions bear some similarities to those demonstrated in recent studies by Liu et al. (2009) and Guo et al. (2013) in their multiyear equilibrium integrations using an atmospheric model with prescribed SSTs. Both those studies indicated that local anthropogenic sulphur dioxide emissions induce a weakening of the EASM and reduced precipitation in a large area over East Asia. Our transient simulations might not reach equilibrium with the forcing changes even at the end of the season and land surface responses to forcing changes in pre-monsoon season are not included in comparison to those in Liu et al. (2009) and Guo et al. (2013). However, the similarities in seasonal mean responses between this study and those in Liu et al. (2009) and Guo et al. (2013) indicate that the weakening of the EASM and reduced precipitation over East Asia in response to local sulphate aerosols are robust features in which the fast atmospheric and land surface responses on seasonal time scale may be the dominant processes.

\subsection{Days 41-90 response to European emissions}

The spatial patterns of time mean changes over days 41-90 of some key variables induced by European sulphur dioxide emissions are illustrated in Fig. 11. European emissions induce large increases in sulphate burden over Europe.
However, the sulphate burden changes range from 0.1 to $1.0 \mathrm{mg} \mathrm{m}^{-2}$ over Asia, which is much smaller than those ( $4-8 \mathrm{mg} \mathrm{m}^{-2}$ ) due to Asia emissions (Fig. 3a). Such small changes in sulphate burden, and therefore in CDNC and CDER, mean that changes in TOA clear sky net SW in response to European emissions are also very small over both central and East Asia (Table 2). However, there are significant decreases in column integrated water vapor over Asia and increases over the WNP (Fig. 11a).

The significant decrease in column integrated water vapor over Asia leads to a reduction in atmospheric heating by SW absorption (e.g., Mitchell et al. 1987), and an increase in surface clear sky net SW, and therefore surface net SW radiation (Fig. 11b; Table 2). The decreased water vapor concentration enhances radiative cooling to space, and therefore results in an increase in clear sky outgoing longwave radiation (a decrease in clear sky TOA LW) (Table 2). The decreased water vapor concentration also reduces the LW radiative cooling of the atmosphere to the surface, leading to a decrease in net surface LW over Asia (Fig. 11c; Table 2). The decrease in cloud cover associated with the reduced water vapor gives rise positive SW cloud radiative effect (CRE) and negative LW CRE (Table 2), leading to large changes in the net SW and LW than the clear sky net SW and LW at both TOA and surface (Table 2). The water vapor feedback may also contribute to a strengthening in the tropospheric cooling over Asia as demonstrated by previous studies (Soden et al. 2002; Gettelman and Fu 2008; Minschwaner et al. 2006). The opposite changes occur over the tropical Indian Ocean and the WNP related to moistening.

The reduction in surface net LW and enhanced upward sensible heat flux (Fig. 11c; Table 2) gives rise to a decrease in surface air temperature over Asia. The cooling at the surface and in the troposphere over Asia, together with warm mid-tropospheric temperature anomalies over the WNP reduces meridional and zonal land-sea thermal contrasts (Fig. 11e, f). This is associated with high SLP anomalies over Asia and low SLP anomalies over the WNP, leading to anomalous northeasterlies over East Asia and a weakening EASM (Fig. 11g). The weakened EASM leads to anomalous moisture transport divergence over East China with reduced convection, anomalous moisture transport convergence and enhanced convection over the WNP and tropical Indian Ocean (Fig. 11h, i). It is interesting to note that, perhaps surprisingly, the circulation response to European emissions is stronger than the response to Asian emissions.

The results above indicate that the tropospheric cooling and drying over Asia in response to European emissions is an important factor for the weakened EASM. This cooling and drying is not induced by changes in local sulphate burden, so what are the processes responsible? Shown in Fig. 12 are time-longitude evolutions of meridionally 
(a) water vapor

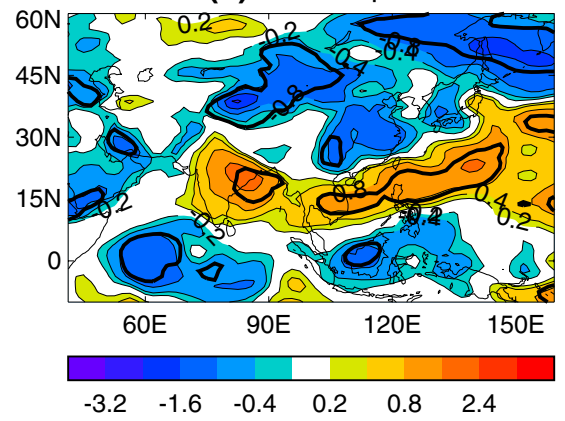

(d) Latent heat

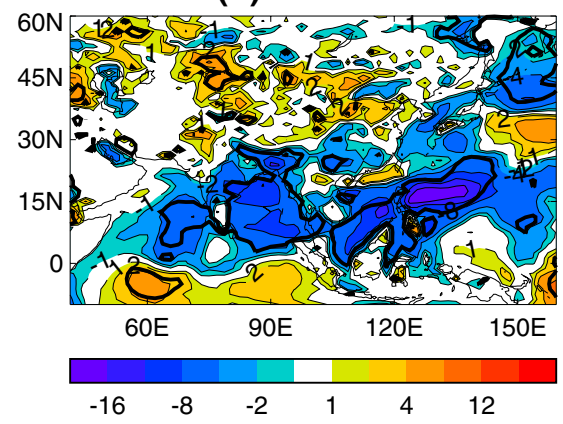

(g) SLP and $850 \mathrm{hPa}$ wind

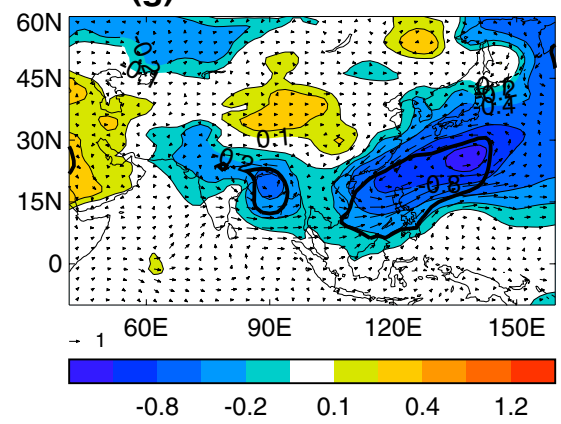

(b) Surface SW

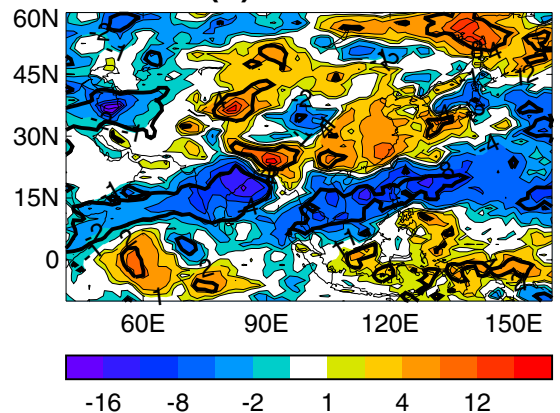

(e) SAT

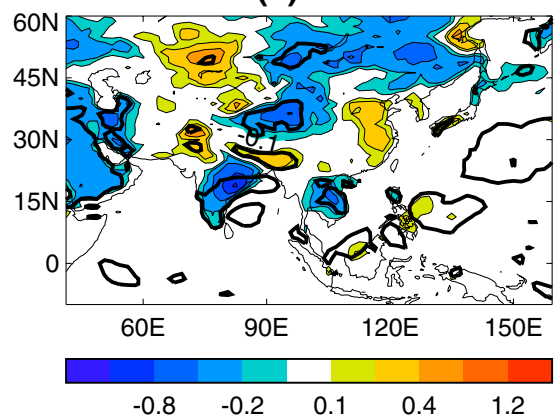

(h) Moisture transport

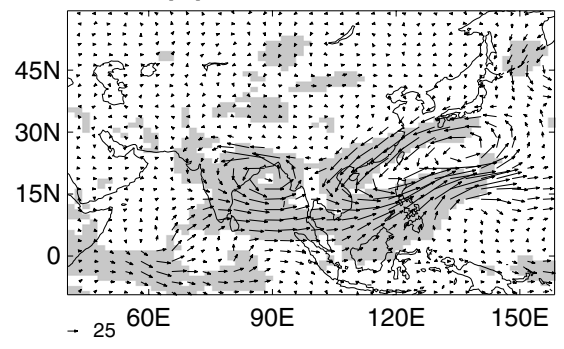

(c) Surface LW

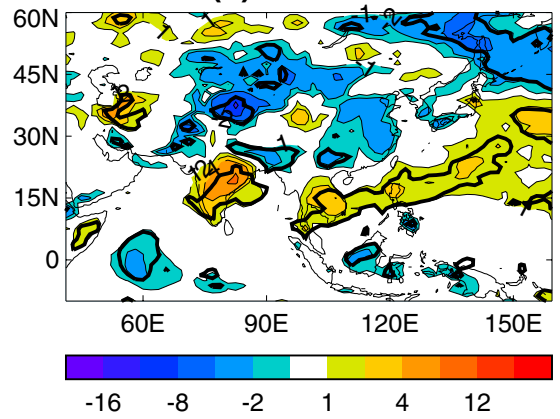

(f) Temperature at $500 \mathrm{hPa}$

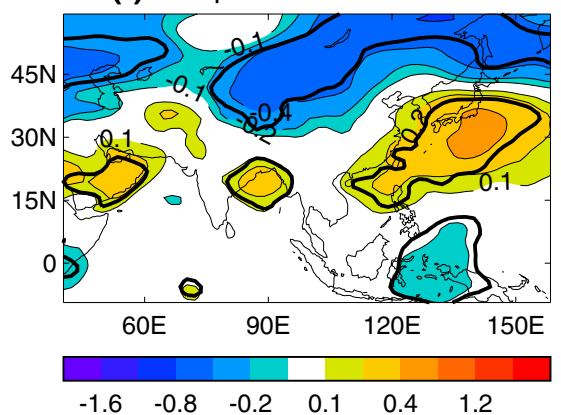

(i) precipitation

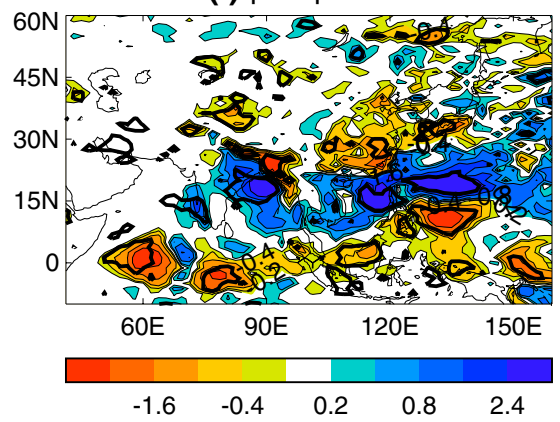

Fig. 11 Days 41-90 mean anomalies in response to European emissions. a column integrated water vapor $\left(\mathrm{kg} \mathrm{m}^{-2}\right)$, b surface $\mathrm{SW}$, c surface LW, d surface latent heat flux, e surface air temperature (SAT, $\left.{ }^{\circ} \mathrm{C}\right)$, f air temperature at $500 \mathrm{hPa}\left({ }^{\circ} \mathrm{C}\right)$, g SLP $(\mathrm{hPa})$ and $850 \mathrm{hPa}$ wind $\left(\mathrm{m} \mathrm{s}^{-1}\right), \mathbf{h}$ vertically integrated water vapor transport $\left(\mathrm{kg} \mathrm{m}^{-1} \mathrm{~s}^{-1}\right)$,

averaged temperature and water vapor over the latitude $25-50^{\circ} \mathrm{N}$ in response to European emissions. Figure 12a shows that coherent surface cooling develops in 2-3 weeks in response to European emissions and the surface cooling is confined mainly to the west of $50^{\circ} \mathrm{E}$. In contrast, time evolutions of changes in both mid-tropospheric temperature and water vapor show eastward propagation features (Fig. 12b, c). The cooling and drying over Europe induced by European emissions propagates downstream into Asia on a time scale of 2-3 weeks. This gives a propagation speed of 3.4-4.4 $\mathrm{m} \mathrm{s}^{-1}$ and it is comparable to the areaaveraged $500 \mathrm{hPa}$ zonal wind of $4.2 \mathrm{~m} \mathrm{~s}^{-1}$, suggesting a dominant role of advection of anomalous temperature and and $\mathbf{i}$ precipitation $\left(\mathrm{mm}\right.$ day $\left.^{-1}\right)$. Radiation and fluxes are in $\mathrm{W} \mathrm{m}^{-2}$ and positive values mean downward. Radiation is the net component. Thick black lines highlight regions where the changes are statistically significant at the $90 \%$ confidence level using a two-tailed Student $t$ test

water vapor by mean flow. These temperature and water vapour anomalies then induce the local feedbacks seen in Fig. 11.

\section{Conclusions}

In this study, we have investigated the impacts of regional sulphur dioxide emissions on the EASM through its impacts on the atmosphere and the surface with an atmospheric general circulation model, excluding SST feedbacks. We examined the transient adjustment processes of the surface and troposphere when either Asian or European 
(a) SAT 25-50N (Europe)

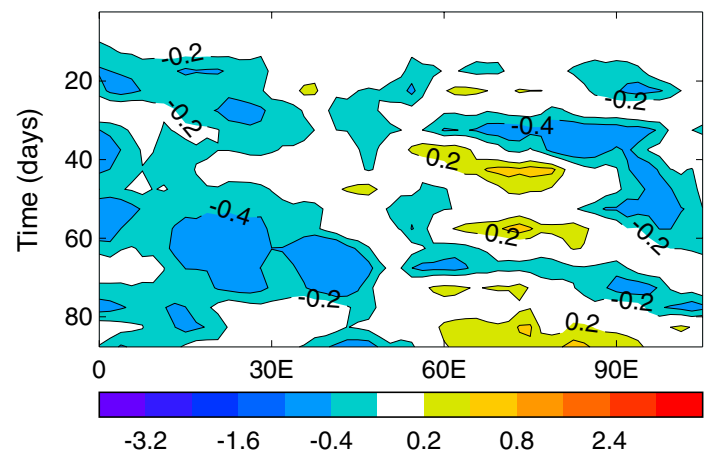

(b) 500 temperature $25-50 \mathrm{~N}$ (Europe)

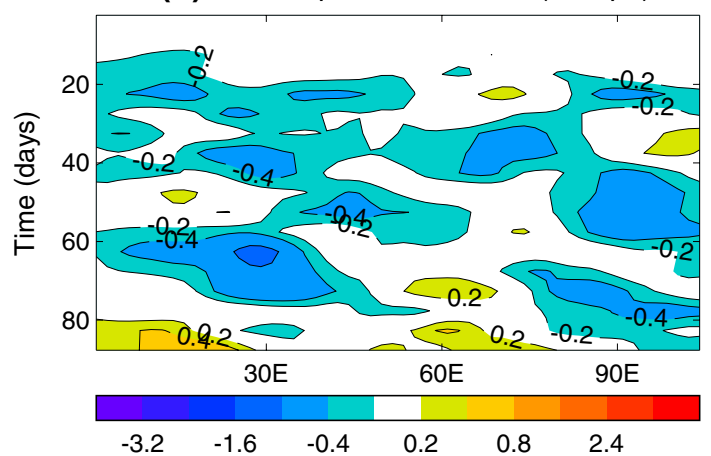

(c) Water vapor $25-50 \mathrm{~N}$ (Europe)

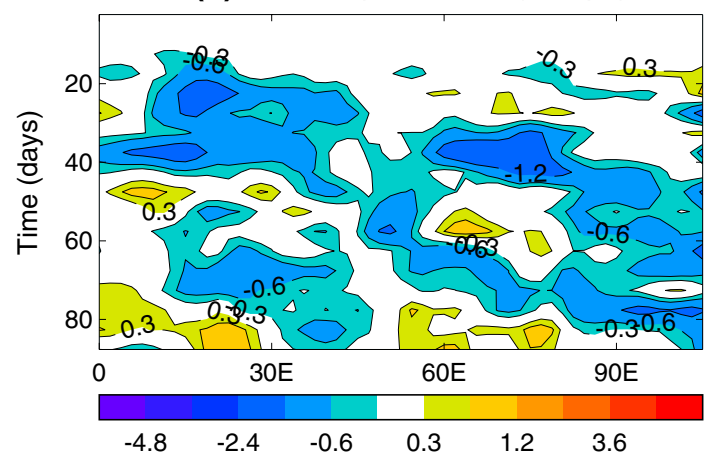

Fig. 12 The time longitude evolutions of 5 day averaged ensemble mean changes averaged over latitude $\left(25^{\circ} \mathrm{N}-50^{\circ} \mathrm{N}\right)$ induced by European sulphur dioxide emissions in June, July, and August. a SAT $\left({ }^{\circ} \mathrm{C}\right)$, b temperature at $500 \mathrm{hPa}\left({ }^{\circ} \mathrm{C}\right)$, and c column integrated water vapor $\left(\mathrm{kg} \mathrm{m}^{-2}\right)$

sulphur dioxide emissions are turned on suddenly. The major processes are summarised schematically in Fig. 13.

- The response to Asian emissions involves a direct impact on the sulphate burden over Asia, with immediate consequences for the SW energy budget. Anthropogenic sulphate reduces the SW reaching the surface and induces a cooling at the land surface by directly scattering the solar radiation (aerosol-radiation interaction), and indirectly increasing the CDNC and decreasing CDER (aerosol-cloud interaction). The cooling at the land surface increases the atmospheric stability, suppresses the convection over East Asia, and reduces the condensational heating from convection. This leads to the free tropospheric cooling over Asia.

- European emissions have no significant impact on the sulphate burden over Asia. However, European emissions induce mid-tropospheric cooling and drying over the European sector. This cooling and drying anomaly is advected into Asia, and induces atmospheric and surface feedbacks.

- The circulation changes in response to both Asian and European emissions are characterized by high SLP anomalies over Asia and low SLP anomalies over the WNP. Cooling and drying of the troposphere over Asia and warming and moistening over the WNP reduce land-sea thermal contrast between Asia and the WNP, causing the weakened EASM circulation. In particular, the warming and moistening over the WNP determines the time scale of EASM response and enhances the changes in land-sea thermal contrast induced by changes over Asian continent either through Asian emissions or European emissions. The weakened EASM leads to a reduction in moisture transport convergence from ocean to land, a decrease in precipitation over East Asia, and an increase over the adjacent oceans.

- The changes in land-sea thermal contrast, atmospheric circulation and local precipitation over East Asia in response to either Asian or European emissions exhibit similar spatial structures and time evolutions, indicating a preferred response.

The results suggest that changes in aerosol emissions over Asia and Europe both influence thermal contrast between Asia and the WNP, affecting the strength of the EASM. This preferred response occurs despite very different perturbations to local aerosols burden in two cases, highlighting the importance of changes in both local and non-local aerosol emissions on the EASM. The impact of local aerosol emissions on the EASM is consistent with the studies of Liu et al. (2009) and Guo et al. (2013) and the non-local impact is in line with Cowan and Cai (2011). Our experiments were deliberately simplified to exclude feedbacks involving changes in sea surface temperatures (SST). Nevertheless it is interesting that the responses to both Asian and European sulphur dioxide emissions we found show some similarities to observed trends in circulation and precipitation during the last 6 decades (Fig. 2f and e) despite some distinct differences. The centre of positive SLP anomalies in the model responses is located near $\left(30^{\circ} \mathrm{N}, 110^{\circ} \mathrm{E}\right)$, which is further south than in the observed trends. The model responses include a negative SLP anomaly over the WNP while observations show little trend there. However, SLP 
Fig. 13 Schematic diagram illustrating the major processes of the EASM responses to Asian and European anthropogenic sulphur dioxide emissions

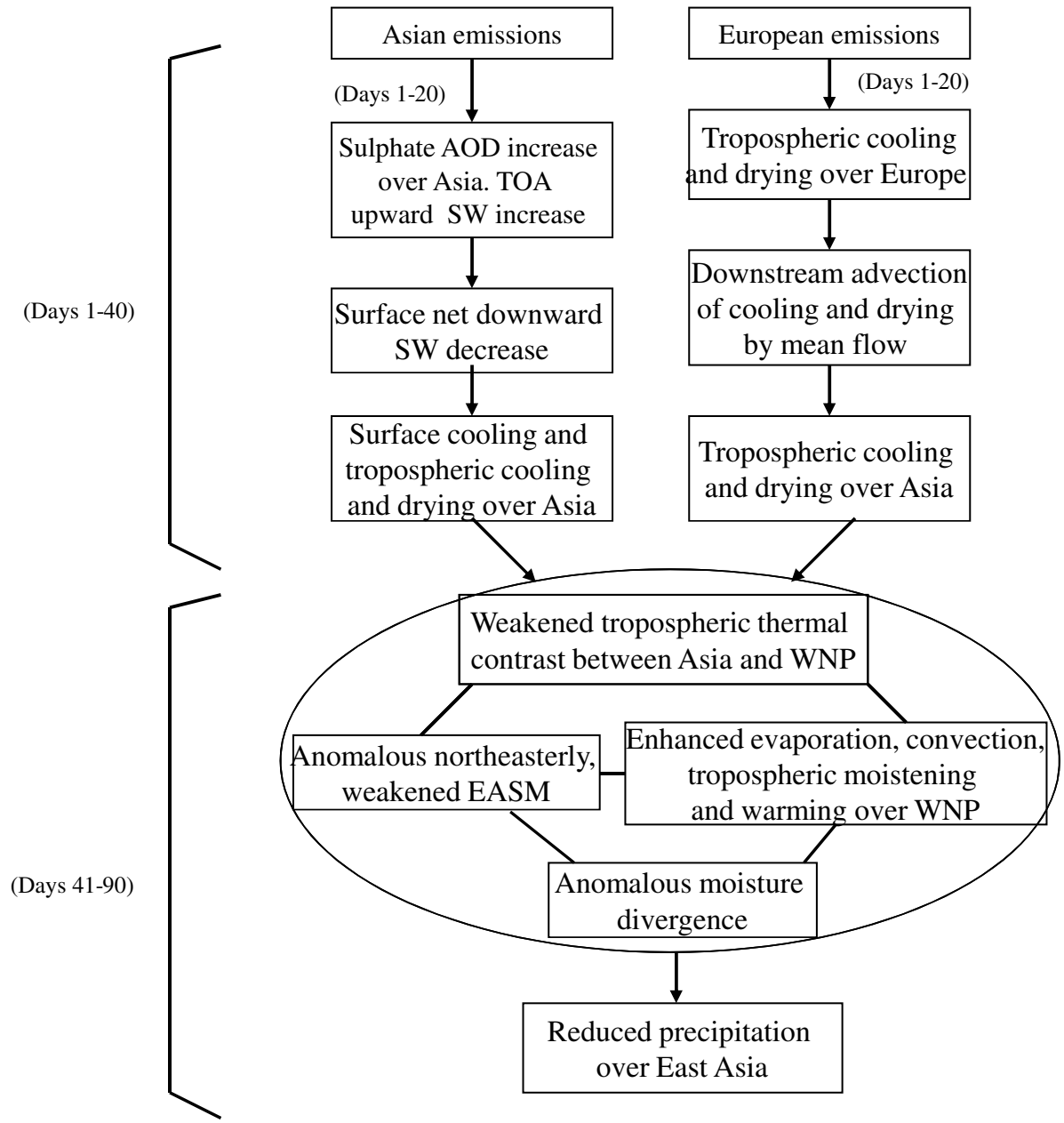

trends over the WNP in observations are sensitive to the specific time period considered, for example Song et al. (2014) show negative SLP trends in this region over the period 1958-2001. The area averaged trend of precipitation over North China $\left(35^{\circ} \mathrm{N}-45^{\circ} \mathrm{N}, 100^{\circ} \mathrm{E}-125^{\circ} \mathrm{E}\right)$ is a decrease of $0.33 \mathrm{~mm} \mathrm{day}{ }^{-1}$ in observations during the last 6 decades. The model responses over the same region show a decrease in precipitation of $0.17 \mathrm{~mm} \mathrm{day}{ }^{-1}$ due to Asian sulphur dioxide emissions and a decrease of $0.23 \mathrm{~mm}$ day $^{-1}$ due to European emissions. The similarities between the responses and observed trends support the idea that sulphate aerosol emissions contributed to the observed decline in precipitation over North China (e.g., Xu 2001; Menon et al. 2002, Liu et al. 2011, Chen et al. 2012, Guo et al. 2013, Jiang et al. 2013, Wang et al. 2013, Polson et al. 2014; Song et al. 2014) and that this decline is associated with tropospheric cooling and drying over Asia (e.g., Yu et al. 2004, Yu and Zhou 2007). Our results further suggest that both Asian and European emissions might have played a role. However, the model responses to local and non-local sulphur dioxide emissions do not show the increase in precipitation over South China as observations indicate, suggesting that other drivers rather than direct impact of the sulphate aerosols through aerosol-radiation and aerosol-cloud interactions might be the main factors for the enhanced precipitation over South China during the last 6 decades.

European emissions of anthropogenic aerosol precursor are decreasing following changes to the Clean Air Acts in the United States and Europe in the early 1990s, while Asian emissions are increasing (e.g., Lamarque et al. 2010). Understanding the roles of these regional changes in anthropogenic aerosol precursor emissions is important for predicting future decadal-scale changes in the EASM. It is highly likely that SST feedbacks will both amplify the responses and modify the pattern (e.g., Ganguly et al. 2012). The SST feedbacks are expected to evolve on timescales of months to decades, longer than those considered in this study. Understanding how these SST feedbacks resulting from local and non-local aerosol emissions modify the relatively fast processes is an important area for future work. 
Acknowledgments This work is supported by PAGODA project of the Changing Water Cycle programme of UK Natural Environment Research Council (NERC) under Grant NE/I006672/1 and the European Union's Seventh Framework Programme [FP7/2007-2013] under grant agreement no 607085. BD, RTS and LW are supported by the U.K. National Centre for Atmospheric Science-Climate (NCASClimate) at the University of Reading. The authors would like to thank two anonymous reviewers for their constructive comments on the early version of the paper.

Open Access This article is distributed under the terms of the Creative Commons Attribution 4.0 International License (http://creativecommons.org/licenses/by/4.0/), which permits unrestricted use, distribution, and reproduction in any medium, provided you give appropriate credit to the original author(s) and the source, provide a link to the Creative Commons license, and indicate if changes were made.

\section{References}

Adler RF et al (2003) The version 2 global precipitation climatology project (GPCP) monthly precipitation analysis (1979-present). J Hydrometeorol 4:1147-1167

Allan R, Ansell T (2006) A new globally complete monthly historical gridded mean sea level pressure dataset (HadSLP2): 1850-2004. J Clim 19:5816-5842

Allen RJ, Sherwood SC (2010) Aerosol-cloud semi-direct effect and land-sea temperature contrast in a GCM. Geophys Res Lett 37:L07702. doi:10.1029/2010GL042759

Bauer SE, Menon S (2012) Aerosol direct, indirect, semi-direct, and surface albedo effects from sector contributions based on the IPCC AR5 emissions for preindustrial and present-day conditions. J Geophys Res 117:D01206. doi:10.1029/2011JD016816

Bayr T, Dommenget D (2013) The tropospheric land-sea warming contrast as the driver of tropical sea level pressure changes. J Clim 26:1387-1402

Bellouin N, Rae J, Jones A, Johnson C, Haywood J, Boucher O (2011) Aerosol forcing in the climate model intercomparison project (CMIP5) simulations by HadGEM2-ES and the role of ammonium nitrate. J Geophys Res 116:D20206. doi:10.1029/2 011JD016074

Bollasina MA, Ming Y, Ramaswamy V, Schwarzkopf MD, Naik V (2014) Contribution of local and remote anthropogenic aerosols to the 20th century weakening of the south Asian monsoon. Geophys Res Lett 41:680-687. doi:10.1002/2013GL058183

Chen HM, Yu RC, Li J, Xin XG, Wang ZZ, Wu TW (2012) The coherent interdecadal changes of East Asia climate in mid-summer simulated by BCC_AGCM 2.0.1. Clim Dyn 39:155-163. doi:10.1007/s00382-011-1154-6

Chou C, Neelin JD, Lohmann U, Feichter J (2005) Local and remote impacts of aerosol climate forcing on tropical precipitation. J Clim 18:4621-4636. doi:10.1175/JCLI3554.1

Collins WJ et al (2011) Development and evaluation of an Earth-system model-HadGEM2. Geophys Model Dev 4:997-1062

Cowan T, Cai W (2011) The impact of Asian and non-Asian anthropogenic aerosols on 20th century Asian summer monsoon. Geophys Res Lett 38:L11703. doi:10.1029/2011g1047268

Dai A et al (2013) The relative roles of upper and lower tropospheric thermal contrasts and tropical influences in driving Asian summer monsoons. J Geophys Res 118:7024-7045. doi:10.1002/ jgrd.50565

Ding YH, Wang ZY, Sun Y (2008) Inter-decadal variation of the summer precipitation in East China and its association with decreasing Asian summer monsoon. Part I: observed evidences. Int $\mathrm{J}$ Climatol 28:1139-1161. doi:10.1002/Joc.1615
Ding YH, Sun Y, Wang ZY, Zhu YX, Song YF (2009) Inter-decadal variation of the summer precipitation in China and its association with decreasing Asian summer monsoon Part II: possible causes. Int J Climatol 29:1926-1944. doi:10.1002/Joc.1759

Dong BW, Gregory JM, Sutton RT (2009) Understanding land-sea warming contrast in response to increasing greenhouse gases. Part I: transient adjustment. J Clim 22:3079-3097

Dong BW, Sutton RT, Highwood E, Wilcox L (2014) The impacts of European and Asian anthropogenic sulphur dioxide emissions on Sahel rainfall. J Clim 27:7000-7017. doi:10.1175/ JCLI-D-13-00769.1

Duan A, Wang M, Lei Y, Cui Y (2013) Trends in summer rainfall over China associated with the Tibetan Plateau sensible heat source during 1980-2008. J Clim 26:261-275. doi:10.1175/JCLI-D-11-00669.1

Fu J, Li S (2013) The influence of regional SSTs on the interdecadal shift of the East Asian summer monsoon. Adv Atmos Sci 30:330-340

Ganguly D, Rasch PJ, Wang H, Yoon JH (2012) Fast and slow responses of the South Asian monsoon system to anthropogenic aerosols. Geophys Res Lett 39:L18804. doi:10.1029/201 2GL053043

Gettelman A, Fu Q (2008) Observed and simulated upper-tropospheric water vapor feedback. J Clim 21:3282-3289

Grabowski WW (2006) Impact of explicit atmosphere-ocean coupling on MJO-like coherent structures in idealized aquaplanet simulations. J Atmos Sci 63:2289-2306. doi:10.1175/JAS3740.1

Gu Y, Liou K, Xue Y, Mechoso C, Li W, Luo Y (2006) Climatic effects of different aerosol types in China simulated by the UCLA general circulation model. J Geophys Res 111:D15201. doi:10.1029/2005JD006312

Guo L, Highwood EJ, Shaffrey LC, Turner AG (2013) The effect of regional changes in anthropogenic aerosols on rainfall of the East Asian summer monsoon. Atmos Chem Phys 13:1521-1534

Hansen J, Sato M, Ruedy R (1997) Radiative forcing and climate response. J Geophys Res 102:6831-6864. doi:10.1029/96JD03436

Harris I, Jones PD, Osborn TJ, Lister DH (2014) Updated high-resolution grids of monthly climatic observations-the CRU TS3.10 Dataset. Int J Climatol 34:623-642. doi:10.1002/joc.3711

Huang Y, Chameides W, Dickinson R (2007) Direct and indirect effects of anthropogenic aerosols on regional precipitation over East Asia. J Geophys Res 112:D03212. doi:10.1029/200 6JD007114

Hwang YT, Frierson DMW, Kang SM (2013) Anthropogenic sulfate aerosol and the southward shift of tropical precipitation in the late 20th century. Geophys Res Lett 40:2845-2850. doi:10.1002/ grl.50502

Jiang Y, Liu X, Yang XQ, Wang M (2013) A numerical study of the effect of different aerosol types on East Asian summer clouds and precipitation. Atmos Environ 70:51-63. doi:10.1016/j. atmosenv.2012.12.039

Jones A, Roberts DL, Woodage MJ, Johnson CE (2001) Indirect sulphate aerosol forcing in a climate model with an interactive sulphur cycle. J Geophys Res 106:20293-20310

Jones C et al (2011) The HadGEM2-ES implementation of CMIP5 centennial simulations. Geophys Model Dev 4:543-570. doi:10.5194/gmd-4-543-2011

Kalnay E, Kanamitsu M, Kistler R, Collins W, Deaven D, Gandin L, Joseph D (1996) The NCEP/NCAR 40-year reanalysis project. Bull Am Meteorol Soc 77:437-471

Lamarque JF et al (2010) Historical (1850-2000) gridded anthropogenic and biomass burning emissions of reactive gases and aerosols: methodology and application. Atmos Chem Phys 10:7017-7039

Lei YH, Hoskins B, Slingo J (2011) Exploring the interplay between natural decadal variability and anthropogenic climate change 
in summer rainfall over China. Part I: observational evidence. J Clim 24:4584-4599

Levine RC, Turner AG (2012) Dependence of Indian monsoon rainfall on moisture fluxes across the Arabian Sea and the impact of coupled model sea surface temperature biases. Clim Dyn 38:2167-2190. doi:10.1007/s00382-011-1096-Z

Li H, Dai A, Zhou T, Lu J (2010) Responses of East Asian summer monsoon to historical SST and atmospheric forcing during 1950-2000. Clim Dyn 34:501-514

Liu Y, Sun J, Yang B (2009) The effects of black carbon and sulfate aerosols in China regions on East Asia monsoons. Tellus B 61:642-656

Liu X, Xie X, Yin ZY, Liu C, Gettelman A (2011) A modeling study of the effects of aerosols on clouds and precipitation over East Asia. Theor Appl Climatol 106:343-354

Martin GM, Milton SF, Senior CA, Brooks ME, Ineson S, Reichler T, Kim J (2010) Analysis and reduction of systematic errors through a seamless approach to modeling weather and climate. J Clim 23:5933-5957. doi:10.1175/2010JCLI3541.1

Menon S, Hansen J, Nazarenko L, Luo YF (2002) Climate effects of black carbon aerosols in China and India. Science 297:2250-2253

Minschwaner K, Dessler AE, Sawaengphokh P (2006) Multimodel analysis of the water vapor feedback in the tropical upper troposphere. J Clim 19:5455-5464

Mitchell J, Wilson CA, Cunnington WM (1987) On CO 2 climate sensitivity and model dependence of results. Q J R Meteorol Soc 113:293-322

Polson D, Bollasina M, Hegerl GC, Wilcox LJ (2014) Decreased monsoon precipitation in the Northern hemisphere due to anthropogenic aerosols. Geophys Res Lett. doi:10.1002/201 4GL060811

Rayner NA et al (2003) Global analyses of sea surface temperature, sea ice, and night marine air temperature since the late nineteenth century. J Geophys Res 108:4407. doi:10.1029/2002JD002670

Rosenfeld D et al (2008) Flood or drought: how do aerosols affect precipitation? Science 321:1309-1313. doi:10.1126/ science. 1160606

Soden BJ, Wetherald R, Stenchikov G, Robock A (2002) Global cooling after the eruption of Mount Pinatubo: a test of climate feedback by water vapor. Science 296:727-730

Song F, Zhou T, Qian Y (2014) Responses of East Asian summer monsoon to natural and anthropogenic forcings in the 17 latest CMIP5 models. Geophys Res Lett 41:596-603. doi:10.1002/20 13GL058705

State Environmental Protection Administration of China (2005) Report on the state of the environment in China 2004. State Environmental Protection Administration of People's Republic of China, Beijing. http://www.zhb.gov.cn/english/SOE/soechina2004/air.htm

Stevens B, Feingold G (2009) Untangling aerosol effects on clouds and precipitation in a buffered system. Nature 461:607-613. doi:10.1038/nature08281

Tao SY, Chen L (1987) A review of recent research on the East Asian summer monsoon in China. In: Chang CP, Krishnamurti TN (eds) Monsoon Meteorology, vol 7. Oxford University Press, Oxford, pp 60-92
Tao WK, Chen JP, Li Z, Wang C, Zhang C (2012) Impact of aerosols on convective clouds and precipitation. Rev Geophys 50:RG2001 doi:10.1029/2011RG000369

Twomey S (1977) Influence of pollution on shortwave albedo of clouds. J Atmos Sci 34:1149-1152

Wan JH, Mahmood R, Li S (2013) Impact of European black carbon on East Asian summer climate. Atmos Ocean Sci Lett 6:375380. doi:10.3878/j.issn.1674-2834.13.0037

Wang C (2013) Impact of anthropogenic absorbing aerosols on clouds and precipitation: a review of recent progresses. Atmos Res 122:237-249. doi:10.1016/j.atmosres.2012.11.005

Wang B, Huang F, Wu Z, Yang J, Fu X, Kikuchi K (2009) Multi-scale climate variability of the South China Sea monsoon: a review. Dyn Atmos Oceans 47:15-37

Wang T, Wang H, Otterå OH, Gao Y, Suo L, Furevik T, Yu L (2013) Anthropogenic forcing of shift in precipitation in Eastern China in late 1970s. Atmos Chem Phys Discuss 13:1199-712032. doi:10.5194/acpd-13-11997-2013

Webster PJ (1987) The elementary monsoon. In: Fein JS, Stephens PL (eds) Monsoons. Wiley Interscience, New York, pp 3-32

Xu Q (2001) Abrupt change of the mid-summer climate in central east China by the influence of atmospheric pollution. Atmos Environ 35:5029-5040

Yang X, Zhu Y (2008) Interdecadal climate variability in China associated with the Pacific Decadal Oscillation. In: $\mathrm{Fu} \mathrm{C}$ et al (eds) Regional Climate Studies of China. Springer, Berlin, pp 97-118

Ye J, Li W, Li L, Zhang F (2013) "North drying and south wetting" summer precipitation trend over China and its potential linkage with aerosol loading. Atoms Res. doi:10.1016/j. atmosres.2013.01.007

Yu RC, Zhou TJ (2007) Seasonality and three-dimensional structure of the interdecadal change in East Asian monsoon. J Clim 20:5344-5355

Yu RC, Wang B, Zhou TJ (2004) Tropospheric cooling and summer monsoon weakening trend over East Asia. Geophys Res Lett 31:L22212. doi:10.1029/2004GL021270

Zhang $\mathrm{H}$ et al (2012) Simulation of direct radiative forcing of aerosols and their effects on East Asian climate using an interactive AGCM-aerosol coupled system. Clim Dyn 38:1675-1693. doi:10.1007/s00382-011-1131-0

Zhao P, Yang S, Yu RC (2010) Long-term changes in rainfall over eastern China and large-scale atmospheric circulation associated with recent global warming. J Clim 23:1544-1562. doi:10.1175 /2009jcli2660.1

Zhou T, Gong D, Li J, Li B (2009) Detecting and understanding the multi-decadal variability of the East Asian summer monsoonrecent progress and state of affairs. Meteorol Z 18:455-467

Zhou Y, Jiang J, Huang A, La M, Zhao Y, Zhang L (2013) Possible contribution of heavy pollution to the decadal change of rainfall over eastern China during the summer monsoon season. Environ Res Lett 8:044024. doi:10.1088/1748-9326/8/4/044024

Zuo ZY, Yang S, Kumar A, Zhang RH, Xue Y, Jha B (2012) Role of thermal condition over Asia in the weakening Asian summer monsoon under global warming background. J Clim 25:34313436. doi:10.1175/Jcli-D-11-00742.1 